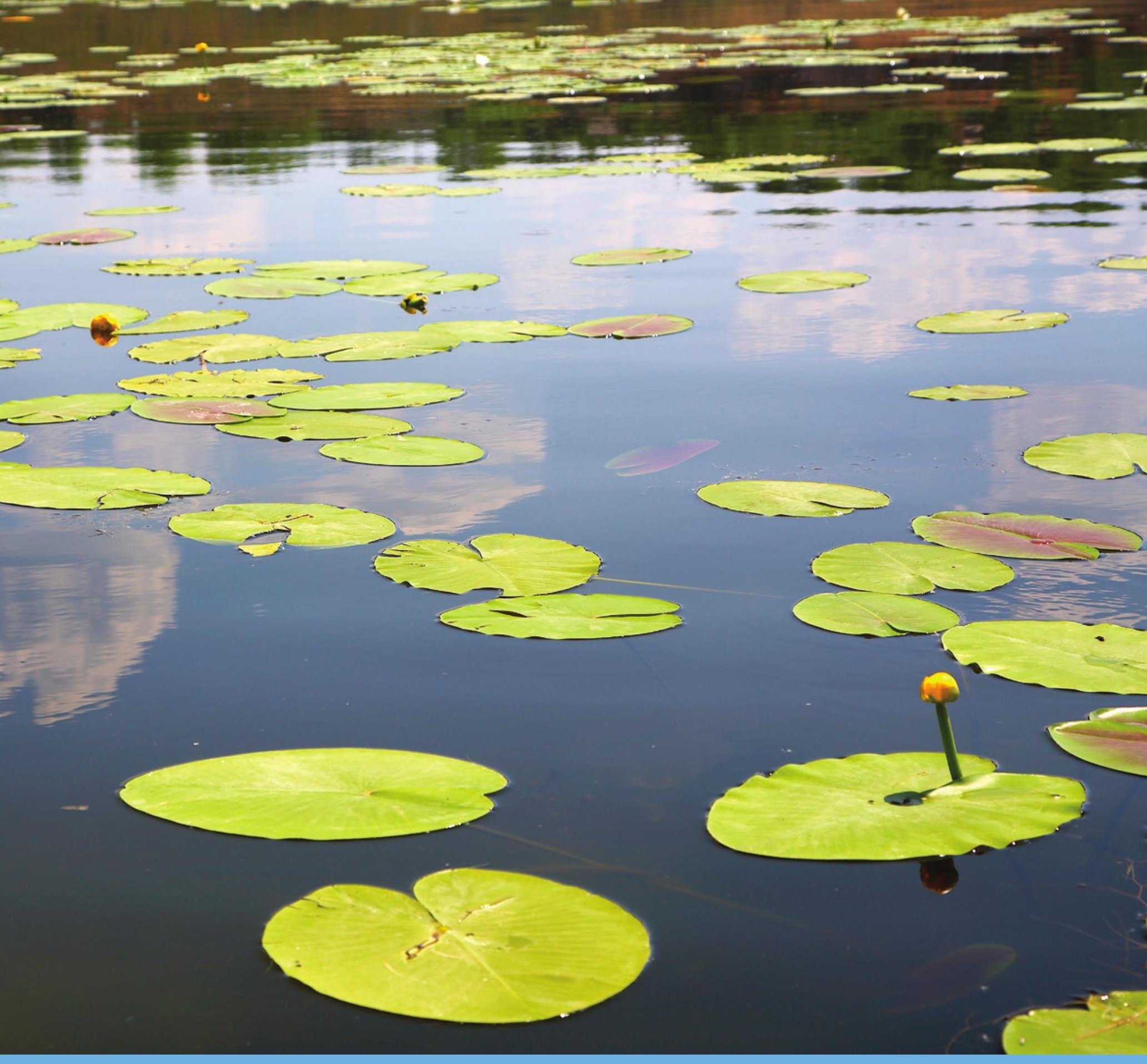

\title{
Vegetatieopnamen als meetnet voor de vochttoestand?
}

Peter Jansen, Tom Hoogland en Martin Knotters

WAGENINGEN

UNIVERSITY \& RESEARCH 



\section{Vegetatieopnamen als meetnet voor de vochttoestand?}

Peter Jansen, Tom Hoogland en Martin Knotters

Dit onderzoek is uitgevoerd door Wageningen Environmental Research in opdracht van en gefinancierd door het ministerie van Landbouw, Natuur en Voedselkwaliteit, in het kader van Kennisbasis Wettelijke Onderzoekstaken (projectnummer KB-24-004-015).

Wageningen Environmental Research

Wageningen, februari 2018

Rapport 2869

ISSN 1566-7197 
Jansen, P.C., T. Hoogland en M. Knotters, 2018. Vegetatieopnamen als meetnet voor de vochttoestand? Wageningen, Wageningen Environmental Research, Rapport 2869. 34 blz.; 9 fig.; 1 tab.; 17 ref.

Grondwaterstanden geven informatie over de vochttoestand van de bodem, maar de samenstelling van natuurlijke vegetaties levert ook informatie hierover. Als beide methoden naast elkaar kunnen worden gebruikt, vergroot dat het meetnet om de vochttoestand te volgen. Potentieel zijn dan duizenden grondwatermeetpunten en tienduizenden vegetatieopnamen op interessante plekken beschikbaar. In dit rapport zijn de gemiddelde voorjaarsgrondwaterstanden (GVG's) die uit grondwatermeetreeksen zijn afgeleid, vergeleken met de GVG's die op dezelfde plek op vijf manieren uit de vegetatiesamenstelling zijn berekend: de lineaire en de exponentiële Ellenbergmethode (SynBioSys), Iteratio, Abiotic Indicators en Estar.

Trefwoorden: vegetatie, vochtindicatie, GVG, tijdreeksmodellering, grondwaterstand

Dit rapport is gratis te downloaden van https://doi.org/10.18174/442190 of op www.wur.nl/environmental-research (ga naar 'Wageningen Environmental Research' in de grijze balk onderaan). Wageningen Environmental Research verstrekt geen gedrukte exemplaren van rapporten.

(C) 2018 Wageningen Environmental Research (instituut binnen de rechtspersoon Stichting Wageningen Research), Postbus 47, 6700 AA Wageningen, T 03174807 00, www.wur.nl/environmental-research. Wageningen Environmental Research is onderdeel van Wageningen University \& Research.

- Overname, verveelvoudiging of openbaarmaking van deze uitgave is toegestaan mits met duidelijke bronvermelding.

- Overname, verveelvoudiging of openbaarmaking is niet toegestaan voor commerciële doeleinden en/of geldelijk gewin.

- Overname, verveelvoudiging of openbaarmaking is niet toegestaan voor die gedeelten van deze uitgave waarvan duidelijk is dat de auteursrechten liggen bij derden en/of zijn voorbehouden.

Wageningen Environmental Research aanvaardt geen aansprakelijkheid voor eventuele schade voortvloeiend uit het gebruik van de resultaten van dit onderzoek of de toepassing van de adviezen. 


\section{Inhoud}

$\begin{array}{ll}\text { Woord vooraf } & 5\end{array}$

$\begin{array}{ll}\text { Samenvatting } & 7\end{array}$

1

$\begin{array}{ll}\text { Inleiding } & 9\end{array}$

1.1 Aanleiding 9

1.2 Probleemstelling 9

$\begin{array}{lll}1.3 & \text { Doel } & 10\end{array}$

1.4 Relatie met ander onderzoek 10

1.5 Opbouw van het rapport 11

1.6 Definities 11

2

$\begin{array}{ll}\text { Aanpak } & 12\end{array}$

$2.1 \quad$ Beschikbare meetlocaties $\quad 12$

2.2 Schatting van GVG's uit tijdreeksen van grondwaterstanden 14

$\begin{array}{lll}2.3 & \text { Schatting van GVG's uit vegetatieopnamen } & 15\end{array}$

$\begin{array}{lll}2.4 & \text { Regressieanalyse } & 15\end{array}$

3

$\begin{array}{ll}\text { Resultaten } & 16\end{array}$

3.1 Meetreeksen Staatsbosbeheer 16

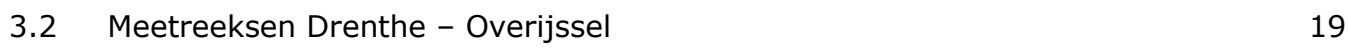

4 Conclusies en aanbevelingen $\quad 23$

4.1 Conclusies $\quad 23$

$\begin{array}{lll}4.2 & \text { Aanbevelingen } & 24\end{array}$

$\begin{array}{ll}\text { Literatuur } & 25\end{array}$

$\begin{array}{ll}\text { Bijlage } 1 & 27\end{array}$

Bijlage 2

$\begin{array}{ll}\text { Bijlage } 3 & 31\end{array}$ 



\section{Woord vooraf}

Dit rapport bevat de analyseresultaten van twee datasets van vegetatieopnamen en grondwaterstandstijdreeksen: een dataset van Staatsbosbeheer en een dataset van de provincies Drenthe en Overijssel. De analyse van de dataset van Staatsbosbeheer is uitgevoerd in opdracht van het ministerie van Economische Zaken, als onderdeel van Kennisbasis Wettelijke Onderzoekstaken 2017, KB-24-004-015. De analyse van de dataset van de provincies Drenthe en Overijssel is uitgevoerd in opdracht van de provincie Overijssel. Omdat het vergelijkbare analyses betrof die beide hetzelfde doel dienden is in goed overleg met de beide opdrachtgevers besloten in één rapport verslag te doen van de onderzoeksresultaten.

Wij zijn ir. Thomas de Meij van de provincie Overijssel, dr. ir. Mirjam Hack-ten Broeke van Wageningen Environmental Research (WENR) en drs. Dennis Walvoort (WENR) erkentelijk voor hun commentaar bij de conceptversie van dit rapport.

Wageningen,

winter 2017/2018,

Peter Jansen, Tom Hoogland en Martin Knotters 


\section{Samenvatting}

Grondwaterstandswaarnemingen en vegetatieopnamen geven een indicatie van de vochtcondities van de bodem. Mogelijk kunnen deze gegevens samen worden gebruikt om veranderingen in de vochttoestand te kunnen volgen. Daarmee zou het aantal waarnemingspunten sterk toenemen. De onderzoeksvragen luidden:

1. Wat zijn de verschillen in de Gemiddelde Voorjaarsgrondwaterstand (GVG), afgeleid uit vegetatieopnamen met behulp van de verschillende instrumenten of methoden die bij de organisaties KWR, Staatsbosbeheer en Alterra zijn ontwikkeld?

2. Wat is de nauwkeurigheid van deze GVG's in vergelijking met die geschat zijn uit tijdreeksen die in peilbuizen zijn waargenomen?

In dit onderzoek is gekeken naar de mate van overeenkomst van de GVG op plekken waar grondwaterstanden zijn gemeten en vegetatieopnamen zijn gemaakt. Er zijn landelijke gegevens gebruikt van de database van Staatsbosbeheer en regionale gegevens uit Drenthe en Overijssel.

Gemeten grondwaterstanden geven direct informatie over het grondwaterregime, maar een meetreeks moet aan verschillende criteria voldoen om er een betrouwbare GVG uit te kunnen berekenen. Met behulp van dagwaarnemingen van neerslag en verdamping kan vaak ook voor (te) korte of onvolledige meetreeksen nog een acceptabel statistisch model worden afgeleid. Dat kan dan een lineair model zijn, of een niet-lineair model als er bijvoorbeeld oppervlakkige drainage of afstroming optreedt. Hier zijn beide berekend, met het softwareprogramma Menyanthes. Met het model met de beste fit zijn dertig jaar neerslag- en verdampingscijfers getransformeerd naar dertig jaar grondwaterstanden, om de meteorologische variatie die in een klimaat voorkomt zo goed mogelijk te bestrijken. Uit de gesimuleerde grondwaterstanden is vervolgens de GVG berekend. In het beperkt aantal gevallen waarin tijdreeksmodellering geen goede fit opleverde, is de GVG zo mogelijk rechtsreeks uit de grondwaterstandswaarnemingen berekend.

Uit de vegetatieopnamen zijn met verschillende instrumenten GVG's afgeleid: Iteratio, Estar, AI (Abiotic Indicatorvalues) en de Ellenberggetallen. De Ellenberggetallen zijn op twee manieren toegepast: lineair en exponentieel. Eerst zijn alleen vegetatieopnamen van Staatsbosbeheer gebruikt. Hoewel voor de instrumenten telkens dezelfde vegetatieopnamen zijn gebruikt, leveren ze verschillende uitkomsten. De onderlinge correlatiecoëfficiënten ( $r$ ) variëren van 0,42 tot $0,77^{1}$. De confrontatie met de GVG's uit de meetreeksen leverde voor geen van de methoden een goed verband op $\left(0,13<r^{2}<0,25\right)$. De beste fit was met Ellenberg-lineair. Zonder enkele uitbijters zouden de correlatiecoëfficiënten met ongeveer 0,1 toenemen.

De uitkomsten voor de dataset van Staatsbosbeheer zijn vergeleken met die voor datasets uit Drenthe en Overijssel. De verbanden tussen de GVG's uit de meetreeksen en de vegetatieopnamen waren voor de dataset van Drenthe en Overijssel niet beter dan die voor de dataset van Staatsbosbeheer. Bij de data van Drenthe en Overijssel is bij een kwart van de locaties een GVG uit de meetreeksen berekend van dieper dan $1 \mathrm{~m}$ (tot meer dan $5 \mathrm{~m}$ ). In de dataset van Staatsbosbeheer kwamen dergelijke diepe GVG's niet voor. Daardoor zijn de richtingscoëfficiënten van de regressielijnen voor de datasets van Drenthe en Overijssel minder groot dan voor de dataset van SBB en hebben de regressiemodellen een grotere residuele standaardafwijking.

De eerste conclusie is dat de verschillende instrumenten om GVG's uit vegetatieopnamen af te leiden geen eenduidige uitkomsten geven, maar grote verschillen vertonen. De voorspellingen op basis van Ellenberg (SynBioSys) vertonen een relatief grote spreiding en zijn gemiddeld relatief ondiep. De GVG's die met AI, Estar en Iteratio worden voorspeld, vertonen relatief weinig spreiding. Estar voorspelt gemiddeld relatief diepe GVG's.

\footnotetext{
1 Voor Ellenberg-lineair en Ellenberg-exponentieel zijn dezelfde getallen gebruikt en is de correlatie 1,0 .
} 
De tweede conclusie is dat de GVG's die uit vegetaties zijn voorspeld niet vergelijkbaar zijn met de GVG's die uit tijdreeksen van grondwaterstanden zijn geschat. De regressiemodellen die de relatie tussen de GVG uit tijdreeksen en de GVG uit vegetatieopnamen beschrijven, hebben residuele standaardafwijkingen variërend van $17 \mathrm{~cm}$ (dataset Staatsbosbeheer, methode Ellenberg) tot $104 \mathrm{~cm}$ (dataset Drenthe-Overijssel, methode Abiotische Indicatoren). Voor het nauwkeurig en gedetailleerd in kaart brengen van de GVG ten behoeve van verdroging is het aantrekkelijk zowel grondwaterstanden in peilbuizen als grondwaterstanden afgeleid uit vegetatieopnamen te combineren, om zodoende het meetnet te verdichten. Samenvoegen van GVG's uit beide bronnen vereist echter dat beide vergelijkbare resultaten opleveren, maar uit deze analyse blijkt dat niet het geval te zijn. Er zijn diverse oorzaken denkbaar waardoor de nauwkeurigheid waarmee GVG's uit vegetaties worden voorspeld laag is:

a. De instrumenten waarmee de GVG's uit de vegetatieopnamen zijn afgeleid, zijn wel geschikt voor specifieke standplaatsen, maar ongeschikt voor een regionale of landelijke toepassing.

b. Vegetaties worden niet zozeer bepaald door langjarige hydrologische condities, zeg gemiddelde condities over een periode van dertig jaar, maar meer door schommelingen met een kortere tijdspanne. Omdat de GVG langjarige condities (dertig jaar) karakteriseert, zijn vegetaties met hogere dynamiek daarom minder geschikte voorspellers voor de GVG.

c. Vegetaties kunnen na-ijlen ten opzichte van wijzigingen in het hydrologisch regime, waardoor ze een eerdere hydrologische situatie vertegenwoordigen dan de actuele.

d. Veranderingen in de vochttoestand kunnen op verschillende standplaatsen anders uitpakken als gevolg van verschillen in bodemopbouw en samenstelling van het grondwater.

e. $\mathrm{Er}$ is geen relatie tussen de grondwaterstand en de hoeveelheid en samenstelling van het vocht dat beschikbaar is voor de vegetatie. Dit zal vooral bij hangwaterprofielen het geval zijn.

Samenvattend is er geen generale oorzaak aan te wijzen waardoor de uitkomsten uiteenlopen. Op iedere plek kan dat anders zijn.

Dit onderzoek leidt tot de volgende aanbevelingen:

1. Cruciaal voor een goede analyse van de nauwkeurigheid waarmee uit vegetaties GVG's kunnen worden voorspeld, is dat de locaties van peilbuizen en vegetatieopnamen samenvallen of in elk geval overeenkomstige abiotische condities vertegenwoordigen. Wij bevelen aan om op basis van veldkennis en nauwkeurige informatie over ruimtelijke coördinaten de datasets te screenen. Herhaling van de analyses met een gescreende dataset kan wellicht resulteren in hogere voorspelnauwkeurigheden.

2. Wij bevelen aan om de instrumenten om GVG's uit vegetatie te voorspellen, te verbeteren, door meer gewicht te geven aan de minder dynamische eigenschappen van een vegetatie. De GVG is immers een karakteristiek voor langjarige hydrologische condities (30 jaar).

3. Omdat de relatie tussen vegetatie en GVG afhangt van bodemkundige en hydrologische omstandigheden, bevelen wij aan om in de instrumenten die de GVG uit vegetatie voorspellen meer differentiatie aan te brengen naar deze omstandigheden.

Ook de meetreeksen en de daarop toegepaste analyses kunnen tot onjuiste uitkomsten leiden. Striktere selecties van meetplekken leiden tot hooguit een bescheiden verbetering van de berekende GVG - en daarmee tot een beter inzicht in de verdroging -, maar het resulteert niet tot een betere overeenkomst met de GVG die is afgeleid uit de vegetatie. De belangrijkste conclusie uit dit onderzoek is dan ook dat de vochtindicatie uit vegetaties op landelijke en regionale schaal geen aanvulling vormen op de informatie die uit gemeten grondwaterstanden wordt verkregen. Op lokaal niveau is dat mogelijk wel het geval. 


\section{$1 \quad$ Inleiding}

\section{$1.1 \quad$ Aanleiding}

Informatie over de grondwaterstand wordt onder meer gebruikt in het verdrogingsbeleid, bij het berekenen van schade-uitkeringen aan agrariërs in waterwingebieden, bij het schatten van de uitspoeling van nutriënten naar het grondwater en bij de voorbereiding van civieltechnische werken. Beleidsmakers en waterbeheerders moeten rekening houden met meerdere, vaak tegengestelde belangen ten aanzien van de grondwaterstand. Daarom moeten grondwaterbeheerders beschikken over nauwkeurige informatie. Om risico's te kunnen inschatten en beheersen, moet de nauwkeurigheid van deze informatie bekend zijn. Discussies over de kwaliteit en uniformiteit van grondwaterstandsinformatie leidden er mede toe dat het sinds 2004 ontbreekt aan een landelijk beeld van de trendmatige verandering van de grondwaterstand in het areaal verdroogde natuur.

Het Planbureau voor de Leefomgeving (PBL) rapporteert in de Balans van de Leefomgeving periodiek over de voortgang en de effectiviteit van het milieu- en natuurbeleid en kijkt vooruit in de Natuurverkenningen. In het kader van het Natuurpact (Bestuursakkoord Natuur, 2012) analyseert PBL de verdrogingstoestand en de voortgang van verdrogingsbestrijding in opdracht van het ministerie van EZ. Tot 2004 vervaardigde het IPO landelijke overzichten van de verdroging van natuurterreinen. Sindsdien is er geen systematische landsdekkende inventarisatie van de verdroging van natuurgebieden meer geweest, waardoor een landelijk overzicht van de effecten van lokaal en regionaal antiverdrogingsbeleid ontbreekt.

\section{$1.2 \quad$ Probleemstelling}

Een deel van de informatie die voor het Subsidiestelsel Natuur en Landschap (SNL) en de Habitatrichtlijn wordt verzameld in natuurgebieden van het Natuurnetwerk (NNN) en Natura 2000gebieden door provincies en terreinbeheerders, kan ook worden benut voor het vaststellen van de verdrogingsstatus en mogelijk ook voor de verdrogingstrends. Daarvoor kunnen ten minste twee soorten gegevens worden gebruikt, die beide alleen voor meet- of waarnemingslocaties een indicatie van de vochtcondities opleveren:

1. vegetatieopnamen (en wellicht vegetatiekarteringen);

2. grondwaterstandswaarnemingen.

Met vegetatiegegevens, die centraal zijn opgeslagen in de nationale vegetatiedatabank (TURBOVEG) en bij terreinbeheerders beschikbaar zijn, kunnen via responsecurves abiotische condities worden voorspeld. De abiotische condities, of standplaatsfactoren afgeleid uit vegetatieopnamen over vochtcondities in de wortelzone, omvatten wat betreft het thema Verdroging de Gemiddelde Voorjaarsgrondwaterstand (GVG) en gemiddeld laagste grondwaterstand (GLG) of droogtestress afgeleid uit GLG.

Het voordeel van het gebruik van vegetatiegegevens bij het afleiden van grondwaterstandsinformatie is dat vegetatieopnamen of vegetatiekarteringen voor diverse regelingen verzameld dienen te worden en daardoor ruim voorhanden zijn (>75.000 locaties), waardoor het meetnet ten opzichte van het bruikbare peilbuizennetwerk (2.500 locaties) aanzienlijk verdicht kan worden en in de toekomst door lopende verplichtingen voor het Programma Aanpak Stikstof (PAS) nog verder verdicht wordt.

Deze indirecte methode heeft echter nadelen voor het vaststellen van verdroging. Doordat de vegetatie tijd nodig heeft om zich aan abiotische condities aan te passen, ijlt zij dus na en hoeft er geen directe relatie te zijn tussen vegetatie en actuele abiotische condities. Daarnaast zijn andere factoren op de soortensamenstelling van invloed, zoals de verspreidingssnelheid van soorten, de 
interactie met andere omgevingsfactoren (zoals nutriëntenbeschikbaarheid en zuurgraad) en andere typen milieudruk.

Welke verdrogingsindicatoren uit vegetatieopnamen afgeleid kunnen worden, hangt af van het instrumentarium dat hierbij gebruikt wordt: Iteratio (Holtland et al. 2010), Estar

(www.kwrwater.nl/downloads/estar/ESTAR.zip) of de EC-methode (http://www.abiotic.wur.nl/). De grondwaterstandsmetingen en vegetatieopnamen bieden ook alleen informatie over de abiotische condities op de betreffende locaties.

Voor het nauwkeurig en gedetailleerd in kaart brengen van de GVG en GLG ten behoeve van verdroging is het wenselijk zowel grondwaterstanden in peilbuizen als afgeleid uit vegetatieopnamen te combineren, om zodoende het meetnet van waarnemingen te verdichten. Samenvoegen van GVG uit beide bronnen vereist echter dat beide schattingen nauwkeurige en vergelijkbare resultaten opleveren.

\subsection{Doel}

Het doel is om bij te dragen aan de ontwikkeling van een werkwijze waarmee de verdroging in de toekomst kan worden vastgesteld door beter gebruik te maken van vegetatieopnamen die vanwege andere verplichtingen door de terreinbeheerders worden verzameld.

In deze studie richten we ons alleen op de GVG, omdat dit de enige grondwaterstandskarakteristiek is die door alle instrumenten wordt berekend. De volgende onderzoeksvragen staan centraal:

1. Wat zijn de verschillen in de GVG, afgeleid uit vegetatieopnamen met behulp van de verschillende instrumenten of methoden die bij de organisaties KWR, Staatsbosbeheer en WENR (Alterra) zijn ontwikkeld?

2. Wat is de nauwkeurigheid van deze GVG's in vergelijking met die geschat zijn uit tijdreeksen die in peilbuizen zijn waargenomen?

De ruimtelijke en temporele variatie van de grondwatersituatie maken het noodzakelijk om een gerichte vergelijking te maken tussen de situatie afgeleid uit grondwaterstandstijdreeksen enerzijds en uit vegetatieopnamen anderzijds. Als extrapolatie naar landelijk geldende uitspraken noodzakelijk is, dient daarnaast zowel een evenwichtige ruimtelijke verdeling van de (meet)locaties als een evenwichtige verdeling over vegetatietypen bereikt te worden.

\subsection{Relatie met ander onderzoek}

Lock et al. (2015) inventariseerden de rekentools die beschikbaar zijn om uit vegetatiegegevens abiotische condities te voorspellen en onderwierpen deze tools aan een theoretische analyse door prof. Cajo ter Braak. Deze inventarisatie omvatte de rekenmodellen Abiotic Indicatorvalues (AI, Wieger Wamelink, Wageningen Environmental Research (Alterra)), ESTAR (Flip Witte, KWR), Indica (Camiel Aggenbach en Edu Dorland, KWR), Iteratio (Jan Holtland, Staatsbosbeheer) en SynBioSys (op basis van Ellenberggetallen, Stephan Hennekens, Wageningen Environmental Research (Alterra)). De aanbeveling van prof. Cajo ter Braak om de verschillende modellen (weak learners) te combineren tot een super learner zal in het kader van deze studie niet worden uitgewerkt. De mogelijkheid wordt onderzocht om dit als case op te nemen in een project dat in opdracht van Wettelijke Onderzoekstaken Natuur en Milieu (WOt N\&M) zal worden uitgevoerd naar big data en datakwaliteit (Vullings en Walvoort, 2016).

Een aanpak die is gebaseerd op peilbuislocaties waarvoor al een gedegen beschrijving van zowel de vegetatie als de abiotische condities beschikbaar is (Hommel et al. 2006; De Waal en Hommel, 2013) laat geen validatie toe. Dit komt doordat de gegevens die op deze meetlocaties zijn verzameld deels al gebruikt zijn voor de ontwikkeling en kalibratie van het model Iteratio (Holtland et al. 2010) en waarschijnlijk ook andere instrumenten waarmee de grondwatersituatie uit vegetatieopnamen wordt voorspeld. Bovendien laat de grondwatersituatie die beschreven is voor deze peilbuislocaties zich 
lastig vertalen naar een landelijk overzicht, omdat de ruimtelijke spreiding van de meetlocaties niet gelijkmatig is noch volgens een bekend steekproefontwerp is geselecteerd.

Van Delft et al. (2017) vergeleken GVG-schattingen uit vegetatieopnamen met GVG's die waren geschat uit grondwaterstandstijdreeksen uit nabijgelegen peilbuizen. Deze vergelijking was een eerste verkenning naar de mogelijkheden om vegetatieopnamen te benutten voor een inschatting van de seizoensfluctuatie van de grondwaterstand. De bevindingen uit en tekortkomingen van deze inventarisatie vormen een belangrijke aanleiding voor deze studie, waarin beter beschreven en beter vergelijkbare data worden gebruikt voor locaties waarvoor zowel een vegetatieopname als een grondwaterstandstijdreeks beschikbaar is.

Knotters en Hoogland (2015) onderzochten de wenselijkheid en realiseerbaarheid van een additioneel validatiemeetnet voor grondwaterstandsinformatie voor gebieden met grondwaterafhankelijke natuur. In 2016 is een pilot gestart voor een dergelijk meetnet in het Boetelerveld (Overijssel). Een validatiemeetnet dat naar aanleiding hiervan landelijk eventueel wordt uitgerold, kan worden gebruikt om de nauwkeurigheid te valideren van methoden waarmee de grondwatersituatie wordt beschreven in het kader van antiverdrogingsbeleid.

\subsection{Opbouw van het rapport}

Hoofdstuk 2 beschrijft de beschikbare data, de methoden van schatting van de GVG en de regressieanalyse die is uitgevoerd om de nauwkeurigheid van GVG-voorspellingen uit vegetatieopnamen te analyseren. Hoofdstuk 3 geeft de resultaten van de analyses. Hoofdstuk 4 beantwoordt met conclusies de onderzoeksvragen en geeft een aantal aanbevelingen.

\subsection{Definities}

In dit onderzoek hanteren we de volgende definities:

- VG3: gemiddelde van de grondwaterstanden op 14 maart, 28 maart en 14 april in een bepaald kalenderjaar (Ritzema et al. 2012). Als de grondwaterstand op 1 april is gemeten, vervangt deze in dit onderzoek de VG3 in de schatting van de GVG;

- GVG: gemiddelde van de VG3 over een periode van dertig jaar onder gegeven klimatologische en waterhuishoudkundige omstandigheden (Ritzema et al. 2012). 


\section{Aanpak}

\section{$2.1 \quad$ Beschikbare meetlocaties}

Voor dit onderzoek zijn 150 plekken met grondwaterstanden en vegetatieopnamen uit de dataset van referentiepunten van Staatsbosbeheer beschikbaar (Figuur 2.1, Beets et al. 2000, 2001, ..., 2005). Daarnaast zijn de gegevens van 276 plekken in de zuidoosthoek van Drenthe en in het oosten van Overijssel beschikbaar (Figuur 2.2 en 2.3). Bij de analyse is een aantal plekken om verschillende redenen afgevallen, waardoor het uiteindelijke totale aantal wat lager uitvalt. Van beide datasets zijn de Abiotic Indicatorvalues (AI), ESTAR, Iteratio en SynBioSys (Ellenberggetallen) bekend.

Bij de vegetatieopnamen zijn grondwaterbuizen geselecteerd waar, tot voor kort of nog steeds, de freatische grondwaterstand wordt gemeten en waarvan de gegevens in het grondwaterarchief DINO van TNO zijn vastgelegd. Van de metingen in DINO is de kwaliteit van de waarnemingen gewaarborgd (www.dinoloket.nl), maar niettemin is verdere controle op meetfouten, trendbreuken etc. nodig alvorens deze gegevens te gebruiken. Bij een aantal vegetatieopnamen staan de peilbuizen in de directe omgeving. Van de andere plekken staan de peilbuizen op enige afstand. Omgekeerd komt het ook voor dat voor één meetbuis meerdere opnamen in aanmerking komen. In die situaties bleken de GVG-indicaties van de verschillende opnamen weinig te variëren. Daarom zijn voor het onderzoek de gemiddelden gebruikt.

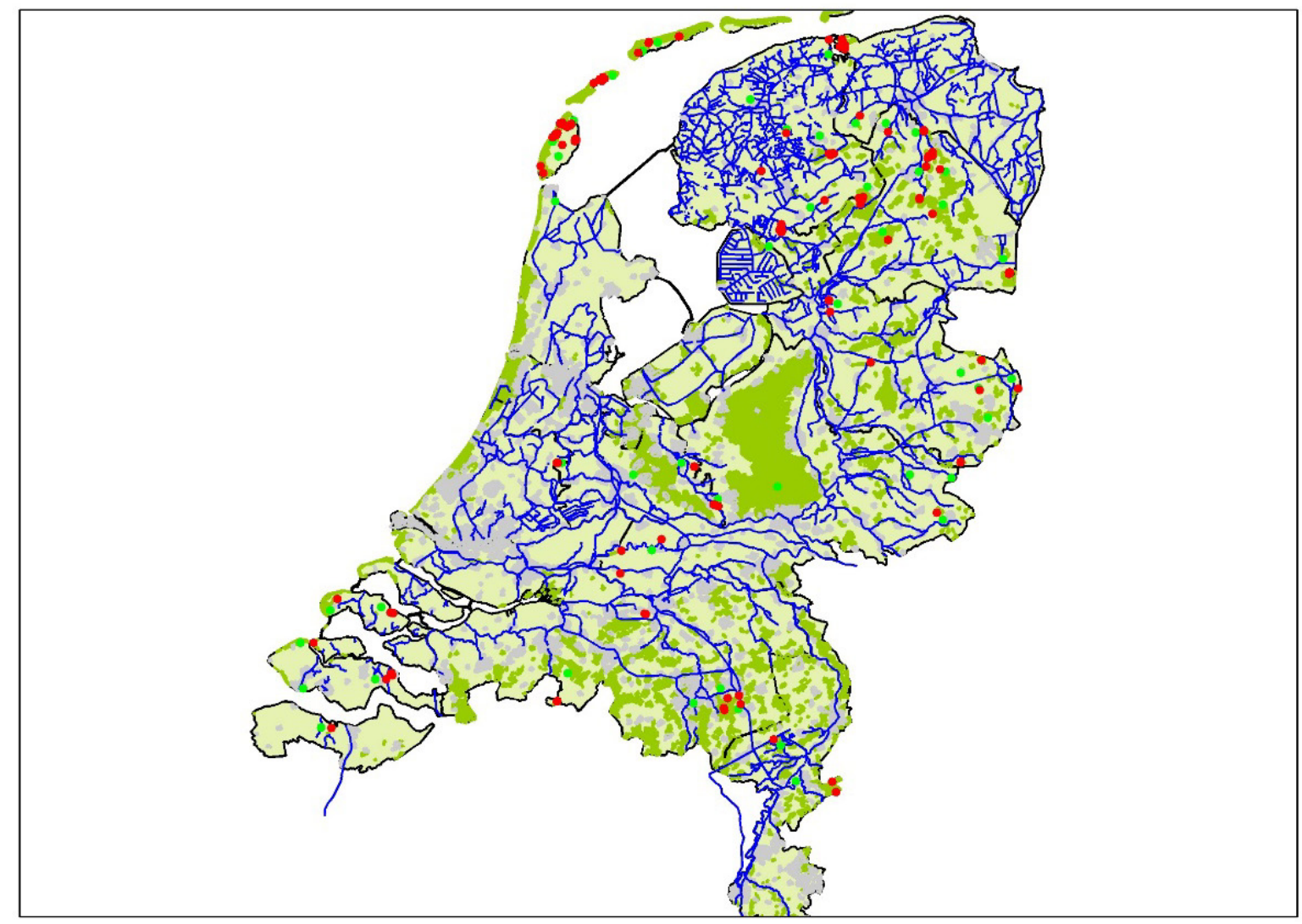

Figuur 2.1 Overzicht van de geselecteerde meetlocaties van Staatsbosbeheer (rood) en de gebruikte neerslagstations van het KNMI (groen). 


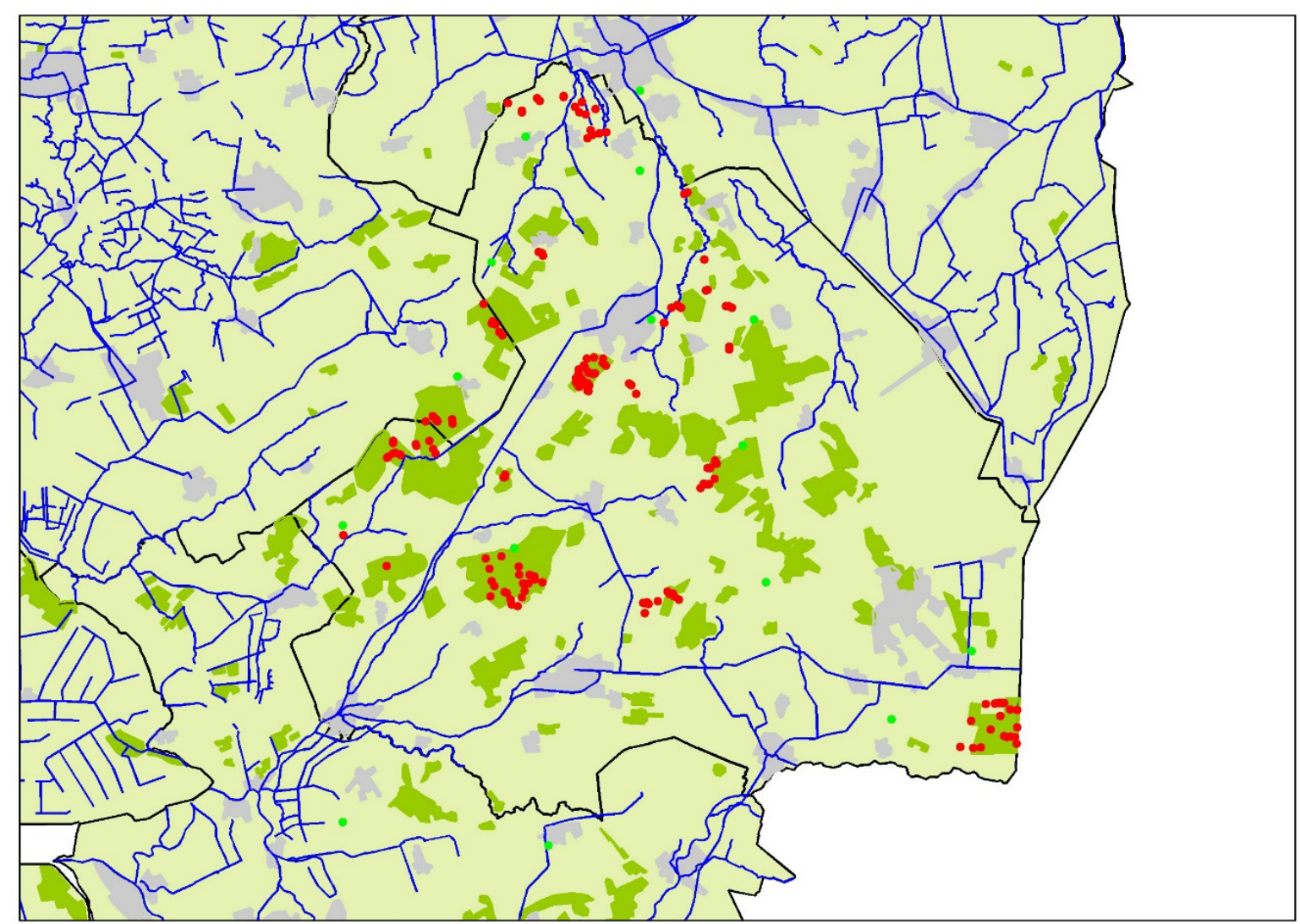

Figuur 2.2 Overzicht van de geselecteerde meetlocaties in Drenthe (rood) en de gebruikte neerslagstations van het KNMI (groen).

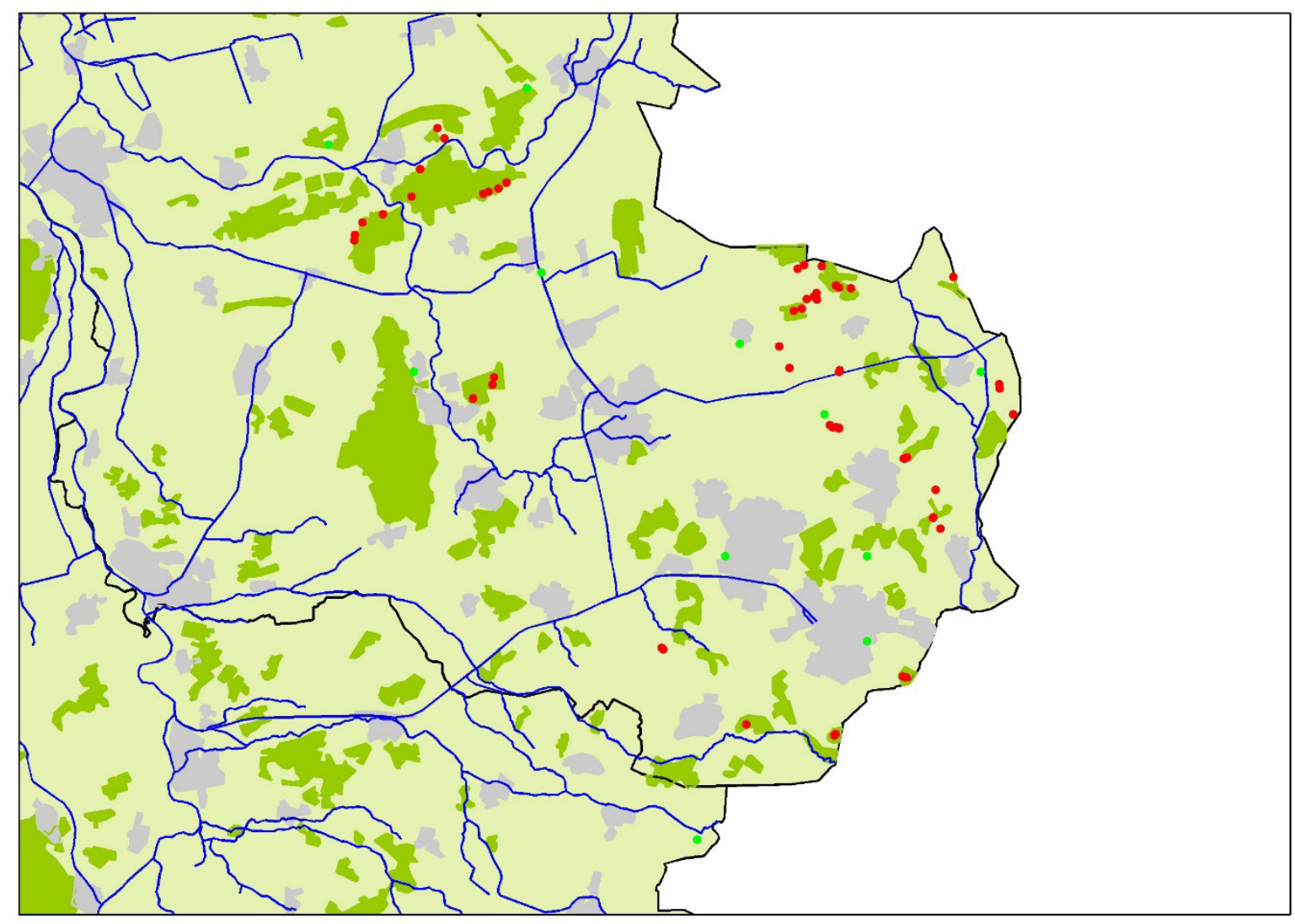

Figuur 2.3 Overzicht van de geselecteerde meetlocaties in Overijssel (rood) en de gebruikte neerslagstations van het KNMI (groen). 


\subsection{Schatting van GVG's uit tijdreeksen van grondwaterstanden}

In deze studie is tijdreeksmodellering uitgevoerd met het softwarepakket Menyanthes (Von Asmuth et al. 2002; Von Asmuth, 2012) waarbij gebruik wordt gemaakt van digitaal beschikbare neerslag- en verdampingsreeksen van het KNMI. Neerslagreeksen met ontbrekende waarden of meetreeksen die niet de volledige periode 1986-2016 omvatten, zijn verwijderd en zijn dus niet gebruikt voor tijdreeksmodellering. Er resteren 41 neerslagstations.

Als verdampingsreeksen met ontbrekende waarden of reeksen met een meetperiode korter dan 19862016 worden verwijderd, dan resteren de reeksen voor Deelen, De Bilt, De Kooy, Leeuwarden en Vlissingen. In Drenthe, Overijssel en Noord-Brabant zouden dan geen verdampingsreeksen beschikbaar zijn. Daarom is voor deze provincies elk een verdampingsreeks samengesteld uit meetgegevens van ieder twee stations. Het station Twente is voor 20 dagen in april 1990 aangevuld met gegevens van station Eelde. Het station Eelde is voor 7 dagen in februari 1989 en 8 dagen in december 1990 aangevuld met gegevens van station Twente. Het station Eindhoven is voor 5 dagen in oktober 1988 aangevuld met gegevens van station Gilze-Rijen. De kalibratie van het tijdreeksmodel vindt plaats voor de periode waarin voor een specifieke buis grondwaterstanden beschikbaar zijn via DINO. Voor alle buizen is in batch een standaard lineair en een standaard niet-lineair tijdreeksmodel (PIRFICT; Von Asmuth et al. 2002) gefit met behulp van Menyanthes. Voor iedere buis is het dichtstbijzijnde neerslag- en verdampingsstation gebruikt.

Met Menyanthes is het mogelijk om een relatie te modelleren tussen neerslag en verdamping enerzijds en grondwaterstand anderzijds met een eenvoudig tijdreeksmodel. Dit model kan lineair zijn of nietlineair. In het niet-lineaire model wordt de grondwaterstandfluctuatie gesplitst in twee regimes, boven en onder een bepaalde drempelwaarde. In beide regimes geldt een lineaire samenhang tussen neerslag en verdamping enerzijds en grondwaterstand anderzijds. Een niet-lineair tijdreeksmodel kan vooral een verbetering ten opzichte van een lineair model zijn in situaties met duidelijke overgangen, bijvoorbeeld een ondiep grondwaterstandsverloop dat wordt afgeroomd door drainagemiddelen.

De grondwaterstandsreeksen zijn visueel beoordeeld op de geschiktheid voor lineaire of niet-lineaire tijdreeksmodellering. In een aantal gevallen zijn de reeksen niet geschikt, bijvoorbeeld als een peilbuis langere perioden droogvalt, er oppervlakkige afvoer optreedt of als de meetreeks een trend vertoont die niet verklaard wordt uit neerslag en verdamping. Bij droogval is gekeken of er een buis in het freatische pakket beschikbaar is met een iets dieper filter, en bij oppervlakkige afvoer voldoet normaliter een niet-lineair model beter. Als er een duidelijke tendens of een sprong in de waarnemingsreeks voorkomt, is zo mogelijk alleen het laatste deel van de meetreeks in beschouwing genomen. Op grond van het laagste Akaike's Information Criterium (AIC) is gekozen tussen een lineair en een drempel-niet-lineair model (Shibata, 1976). AIC maakt een afweging tussen goodness of fit enerzijds en modelcomplexiteit anderzijds en kan worden gezien als een statistisch equivalent van Occam's razor. Als de AIC's van beide gelijk zijn, is voor het lineaire model gekozen. Met de geselecteerde modellen zijn voor een klimaatperiode van dertig jaar (1984-2004) grondwaterstanden gesimuleerd, zodat rekening wordt gehouden met de invloed van natuurlijke variatie van weersschommelingen. Uit deze simulaties zijn de GVG's berekend.

Als het niet mogelijk is om een tijdreeksmodel te kalibreren dat de relatie tussen neerslag en verdamping enerzijds en grondwaterstand anderzijds beschrijft, kan de GVG direct uit de meetreeks worden geschat. Naarmate de meetreeksen korter zijn, zal de seizoenfluctuatie sterker beïnvloed worden door toevallig droge of juist natte omstandigheden in de meetperiode. Voorwaarde voor schatting van de GVG uit een meetreeks is een periode van ten minste zes jaar als het visuele oordeel van de tijdreeksmodellering 'matig' is en vier jaar als het oordeel 'slecht' is. In het laatste geval gaat het vaak om sterk afgeroomde of beheerste regimes waardoor de fluctuaties van neerslag en verdamping nauwelijks in de grondwaterstanden zijn terug te zien en waar de invloed van toevallige droge of natte weersomstandigheden door waterbeheer is geëlimineerd. Grondwaterstandsreeksen met een meetfrequentie die lager is dan twee keer per maand en waarbij niet op of rond 1 april is gemeten, zijn ongeschikt voor de berekening van GVG direct uit de gemeten standen. 


\subsection{Schatting van GVG's uit vegetatieopnamen}

Voor de locaties van de vegetatieopnamen waren schattingen van de GVG bekend die waren gemaakt met de modellen Abiotic Indicatorvalues (AI, Wieger Wamelink, Wageningen Environmental Research (Alterra)), ESTAR (Flip Witte, KWR), Iteratio (Staatsbosbeheer; Holtland et al. 2010) en SynBioSys (op basis van Ellenberggetallen, Hennekens et al. (2010), Wageningen Environmental Research (Alterra)).

\section{$2.4 \quad$ Regressieanalyse}

De samenhang tussen GVG's die uit tijdreeksen van grondwaterstanden zijn voorspeld en de GVG's die met verschillende instrumenten uit vegetatieopnamen zijn voorspeld, is geanalyseerd met behulp van het volgende enkelvoudige lineaire regressiemodel:

$$
y_{i}=\beta_{0}+\beta_{1} x_{i}+\varepsilon_{i}
$$

met $y_{i}$ de GVG die is geschat uit een tijdreeks van grondwaterstanden, $x_{i}$ de GVG die uit een vegetatieopname is voorspeld en $\varepsilon_{i}$ de afwijking tot de regressielijn. De modelparameters en hun standaardfouten geven inzicht in de de samenhang tussen GVG's uit tijdreeksen en GVG's uit vegetaties. De residuele standaardafwijking en de fractie verklaarde variantie geven inzicht in respectievelijk de absolute en relatieve nauwkeurigheid van het regressiemodel dat uit GVG's uit vegetaties GVG's uit tijdreeksen voorspelt. 


\subsection{Meetreeksen Staatsbosbeheer}

Op plekken met meetreeksen die nabij het maaiveld zijn afgetopt, treedt oppervlakkige afvoer op. Deze reeksen konden in de regel goed met het niet-lineaire tijdreeksmodel worden beschreven. In een aantal gevallen bleek dat de reeks niet kon worden gemodelleerd met een lineair of niet-lineair tijdreeksmodel, of dat de meetreeks ongeschikt was, omdat er te weinig waarnemingen beschikbaar waren. Daarnaast was bij verschillende meetbuizen de maaiveldhoogte niet bekend, waardoor geen GVG kon worden bepaald.

Er resteerden 131 plekken waarvoor GVG's uit grondwaterstanden konden worden berekend, hetzij met een tijdreeksmodel, hetzij direct uit de data. Figuur 3.1 geeft scatterplots en regressiemodellen voor de relatie tussen de GVG's uit de meetreeksen en de GVG's die zijn afgeleid uit de lineaire en exponentiële Ellenberggetallen, de Abiotic Indicatorvalues (AI), ESTAR en Iteratio ${ }^{2}$. De verbanden zijn in alle gevallen zwak. Met een fractie verklaarde variatie $R^{2}=0.24$ is het verband tussen de GVG en het Ellenberggetal (lineair) het beste.

Er is ook gekeken of de kwaliteit van de meetreeksen van invloed is op de verbanden. Dat is gedaan voor de volgende selecties van punten:

- het percentage verklaarde variantie van de tijdreeksmodellen die zijn gebruikt om de GVG uit tijdreeksen te schatten is groter dan $70 \%$ (Bijlage 1);

- de visuele beoordeling van de fit van de tijdreeksmodellen is goed of zeer goed (Bijlage 2);

- de meetreeks beslaat minimaal vijf jaar (Bijlage 3).

Het blijkt dat de fit van de regressiemodellen niet verbetert als de regressiemodellering wordt beperkt tot GVG's die zijn geschat met behulp van tijdreeksmodellen met een percentage verklaarde variantie meer dan 70\% (Bijlage 1). Als de regressiemodellering wordt beperkt tot GVG's die zijn geschat met tijdreeksmodellen waarvan de fit visueel als goed is beoordeeld, dan leidt dit tot betere fits bij de regressiemodellering, met uitzondering van Estar, zie Bijlage 2. Opvallend is dat de regressiemodellering juist bij Estar verbetert wanneer de regressiemodellering wordt beperkt tot GVG's die zijn geschat uit reeksen met een lengte van ten minste vijf jaar, zie Bijlage 3. Er zijn enkele uitbijters die de uitkomsten beïnvloeden.

Tabel 3.1 geeft de correlatiecoëfficiënten voor de lineaire samenhang tussen de GVG's die volgens verschillende methoden uit de vegetatieopnamen zijn bepaald. Tussen Ellenberg (lin) en Ellenberg (exp) is de correlatiecoëfficiënt 1.0, omdat hiervoor dezelfde gegevens zijn gebruikt. Tussen Ellenberg en Abiotic Indicatorvalues is het verband het beste. Voor de verbanden met Iteratio levert een kromme een beter verband.

Tabel 3.1 Correlatiecoëfficiënten tussen de verschillende vochtindicaties (GVG's) van vegetatieopnamen.

\begin{tabular}{lccc} 
Ellenberg (exp) & Ellenberg (Iin) & Ellenberg(exp) & Abiotic Int. \\
\hline Abiotic Ind. & $1.0 *$ ) & & \\
\hline ESTAR & 0.77 & 0.71 & 0.45 \\
\hline Iteratio & 0.59 & 0.53 & 0.50 \\
\hline
\end{tabular}

*) met een polynomiale curve ; voor Ellenberg (lin) en Ellenberg (exp) zijn dezelfde gegevens gebruikt.

2 Als er meerdere vegetatieopnamen aan dezelfde meetbuis gekoppeld zijn, is het gemiddelde van GVG's genomen. 


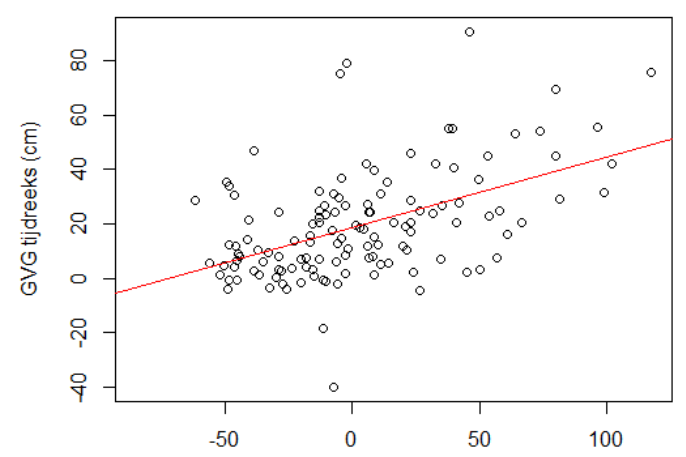

GVG_Ellenberg_lin (cm)
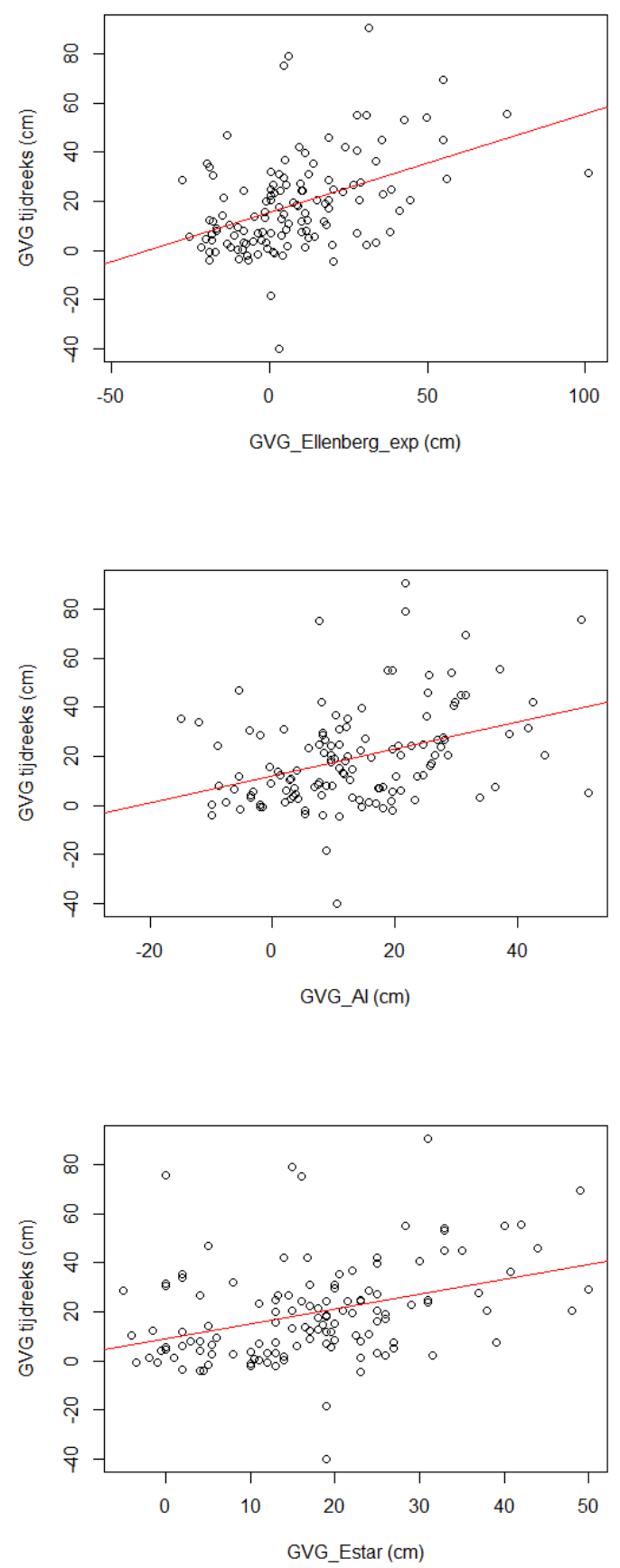

$y=18.62+0.26 x$

(1.55) (0.04)

$\mathrm{S}_{\text {res }}=17.47 \mathrm{~cm}$

$\mathrm{R}^{2}{ }_{\text {adj }}=0.24$

$\mathrm{n}=127$

$$
\begin{aligned}
& \mathrm{y}=15.44+0.40 \mathrm{x} \\
& (1.67) \quad(0.07) \\
& \mathrm{S}_{\text {res }}=17.47 \mathrm{~cm} \\
& \mathrm{R}^{2}{ }_{\text {adj }}=0.19 \\
& \mathrm{n}=125
\end{aligned}
$$

$y=12.03+0.55 x$

(2.34) (0.12)

$\mathrm{S}_{\text {res }}=18.72 \mathrm{~cm}$

$\mathrm{R}^{2}$ adj $=0.13$

$\mathrm{n}=127$

$$
\begin{aligned}
& \mathrm{y}=8.82+0.60 \mathrm{x} \\
& (2.90) \quad(0.14) \\
& \mathrm{S}_{\text {res }}=18.71 \mathrm{~cm} \\
& \mathrm{R}^{2}{ }_{\text {adj }}=0.13 \\
& \mathrm{n}=127
\end{aligned}
$$




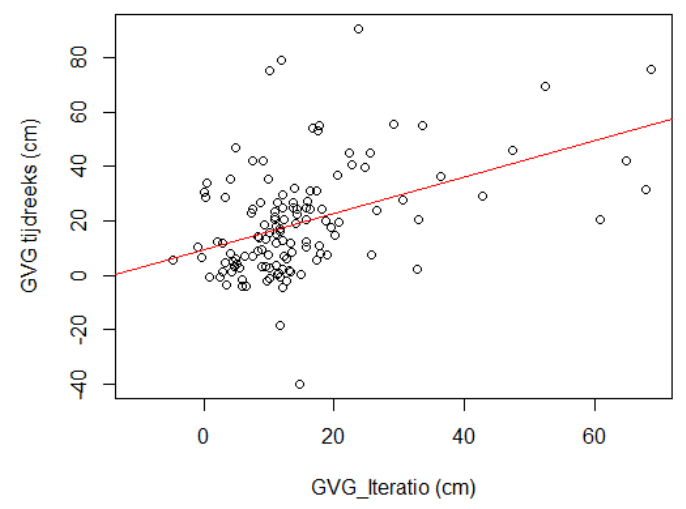

$$
\begin{aligned}
& \mathrm{y}=9.43+0.67 \mathrm{x} \\
& \quad(2.42) \quad(0.12) \\
& \mathrm{S}_{\text {res }}=18.08 \mathrm{~cm} \\
& \mathrm{R}^{2}{ }_{\text {adj }}=0.19 \\
& \mathrm{n}=127
\end{aligned}
$$

Figuur 3.1 Regressiemodellen met de GVG (cm-mv) uit tijdreeksen als afhankelijke variabele en GVG's volgens verschillende indicatiemethoden van de vegetatieopnamen als onafhankelijke variabele (standaardfouten tussen haakjes) op basis van de dataset van Staatsbosbeheer. $s_{\text {res: }}$ residuele standaardafwijking. $R^{2}$ adj. : fractie verklaarde variantie. $n$ : aantal waarnemingen.

Figuur 3.2 geeft voor alle meetplekken boxplots voor GVG's die volgens vijf methoden uit de vegetatiegegevens zijn afgeleid en voor de GVG's die zijn berekend uit tijdreeksen. Er zijn grote verschillen in spreiding. Ellenberg voorspelt gemiddeld relatief ondiepe GVG's, terwijl Estar gemiddeld relatief diepe GVG's voorspelt. 


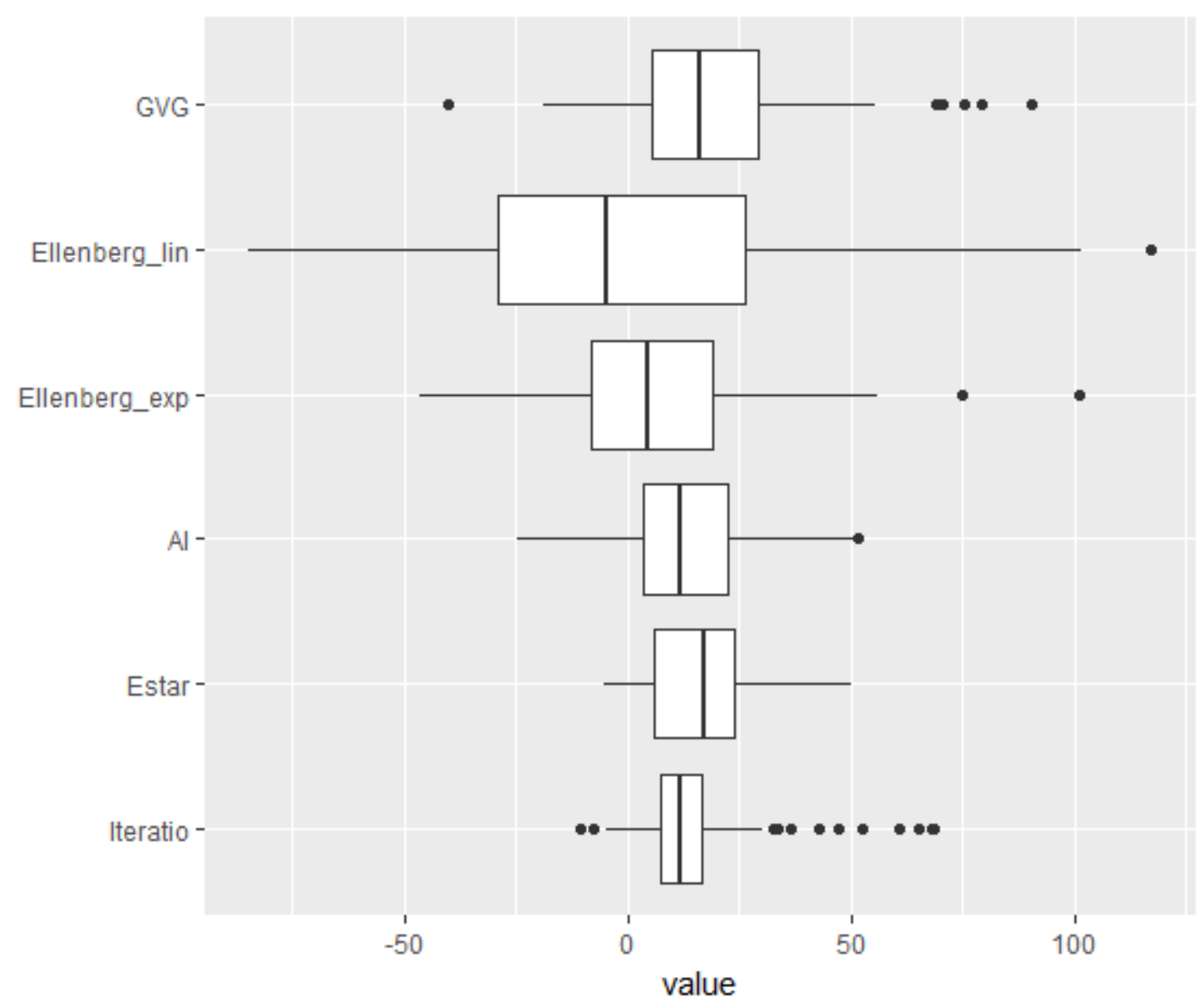

Figuur 3.2 Boxplot van de GVG's die uit tijdreeksen zijn berekend (GVG) en boxplots van GVG's die uit vegetatieopnamen zijn voorspeld met behulp van Ellenberg lineair, Ellenberg exponentieel, Abiotic Indicator Values, Estar en Iteratio, op basis van de dataset van Staatsbosbeheer. Value: berekende GVG in cm-mv.

\subsection{Meetreeksen Drenthe - Overijssel}

De resultaten van de regressieanalyse voor Drenthe en Overijssel zijn afgebeeld in Figuur 3.3. In vergelijking met de dataset van SBB bevat de dataset van Drenthe/Overijssel (Figuur 3.1) veel punten met een, op de grondwaterstandsmetingen gebaseerde, diepe GVG. Bij de SBB-reeks komen geen GVG's dieper dan $1 \mathrm{~m}$ voor, terwijl in Drenthe/Overijssel GVG's tot meer dan $5 \mathrm{~m}$ voorkomen. De GVG's die uit de vegetatiesamenstelling zijn berekend, zijn echter altijd ondieper dan $130 \mathrm{~cm}$. Hierdoor worden voor de dataset Drenthe/Overijssel grotere richtingscoëfficiënten voor het verband tussen GVG's uit grondwaterstanden en GVG's uit vegetatieopnamen gevonden dan voor de dataset van SBB.

Figuur 3.4 geeft een boxplot van de GVG's die zijn geschat uit tijdreeksen en uit vegetatieopnamen volgens vijf methoden. De spreiding van GVG's uit tijdreeksen is groter dan die van GVG's uit vegetatieopnamen. De Ellenbergmethode (lineair) geeft een grotere spreiding in voorspelde GVG's dan de andere methoden. 


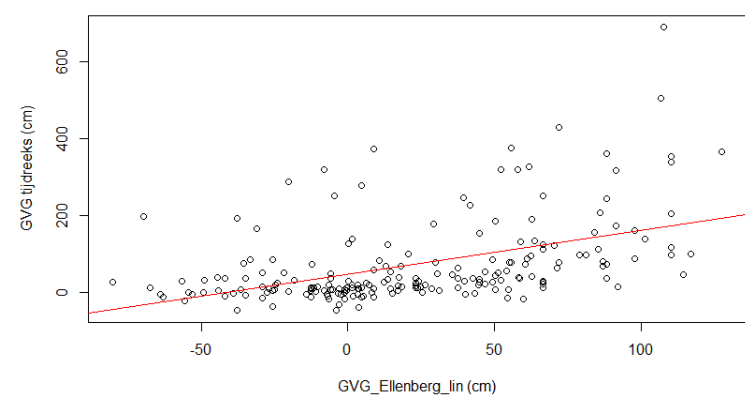

$$
\begin{aligned}
& \mathrm{y}=46.70+1.15 \mathrm{x} \\
& \quad(7.71) \quad(0.15) \\
& \mathrm{S}_{\text {res }}=98.07 \mathrm{~cm} \\
& \mathrm{R}^{2}{ }_{\text {adj }}=0.22 \\
& \mathrm{n}=201
\end{aligned}
$$

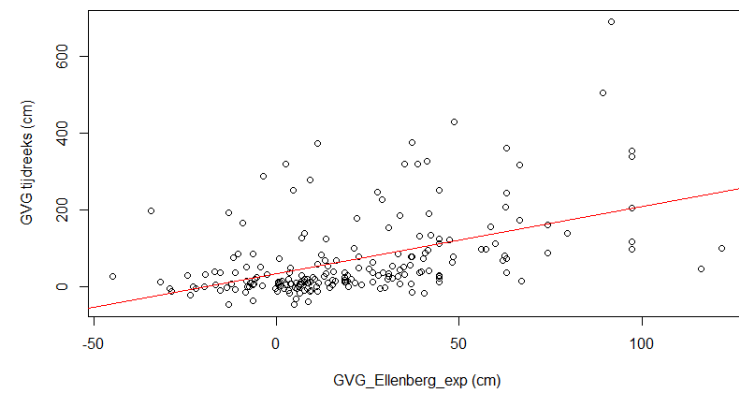

$$
\begin{aligned}
& \mathrm{y}=34.00+1.75 \mathrm{x} \\
& \quad(8.36) \quad(0.23) \\
& \mathrm{S}_{\text {res }}=96.33 \mathrm{~cm} \\
& \mathrm{R}^{2}{ }_{\text {adj }}=0.22 \\
& \mathrm{n}=200
\end{aligned}
$$

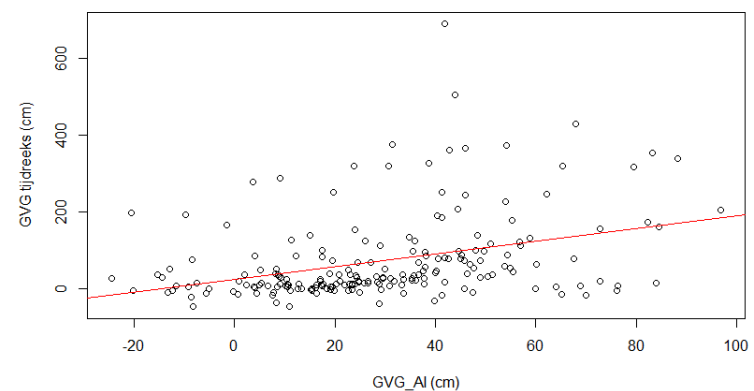

$$
\begin{aligned}
& \mathrm{y}=24.28+1.65 \mathrm{x} \\
& \quad(11.57) \quad(0.31) \\
& \mathrm{S}_{\text {res }}=103.9 \mathrm{~cm} \\
& \mathrm{R}^{2}{ }_{\text {adj }}=0.12 \\
& \mathrm{n}=201
\end{aligned}
$$

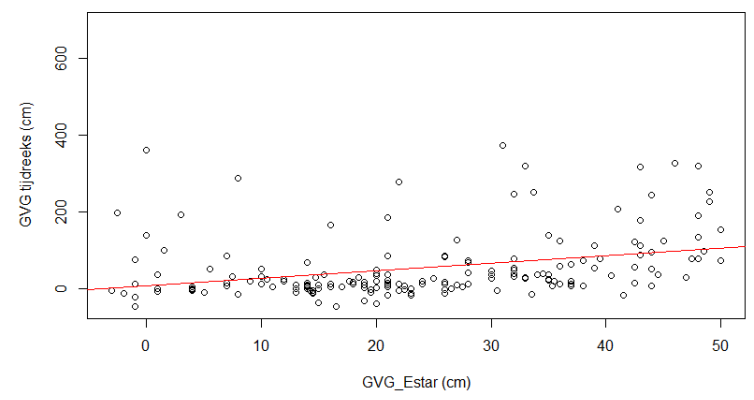

$$
\begin{aligned}
& \mathrm{y}=6.27+2.00 \mathrm{x} \\
& \quad(12.06) \quad(0.44) \\
& \mathrm{S}_{\text {res }}=80.44 \mathrm{~cm} \\
& \mathrm{R}^{2}{ }_{\text {adj }}=0.10 \\
& \mathrm{n}=174
\end{aligned}
$$

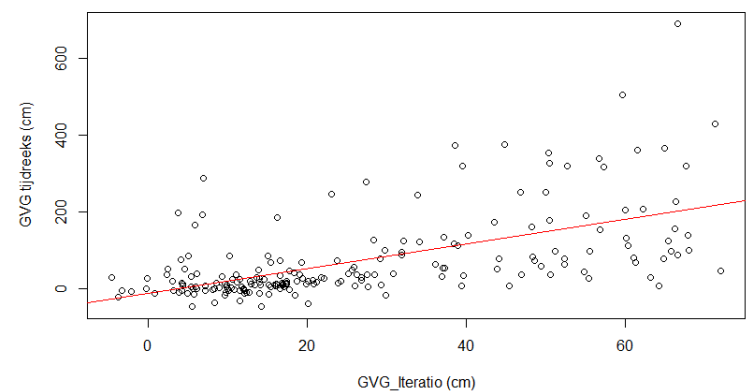

$$
\begin{aligned}
& \mathrm{y}=-12.37+3.20 \mathrm{x} \\
& \quad(10.40) \quad(0.31) \\
& \mathrm{S}_{\text {res }}=89.85 \mathrm{~cm} \\
& \mathrm{R}^{2} \text { adj }=0.34 \\
& \mathrm{n}=201
\end{aligned}
$$

Figuur 3.3 Regressiemodellen met de GVG uit tijdreeksen als afhankelijke variabele en GVG's volgens verschillende indicatiemethoden van de vegetatieopnamen als onafhankelijke variabele (standaardfouten tussen haakjes) op basis van de datasets van Drenthe en Overijssel. sres: residuele standaardafwijking. $R_{\text {adj. }}^{2}$ fractie verklaarde variantie. $n$ : aantal waarnemingen. 


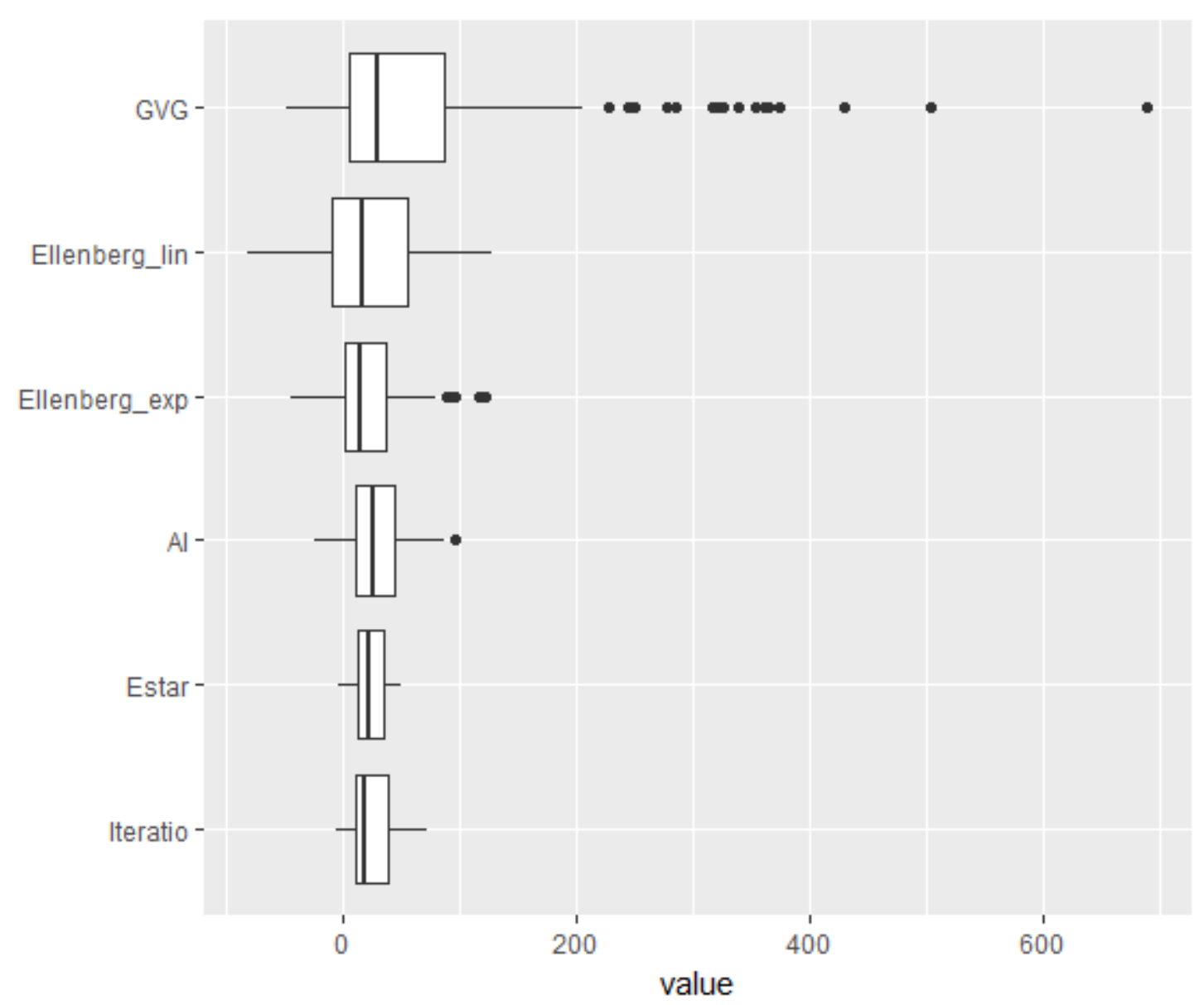

Figuur 3.4 Boxplot van de GVG's die uit tijdreeksen zijn berekend (GVG) en boxplots van GVG's die uit vegetatieopnamen zijn voorspeld met behulp van Ellenberg lineair, Ellenberg exponentieel, Abiotic Indicator Values, Estar en Iteratio, op basis van de datasets van Drenthe en Overijssel. Value: berekende GVG in cm-mv.

Er zijn verschillende oorzaken voor de verschillen tussen de regressiemodellen voor de set van Staatsbosbeheer (Figuur 3.1) en de set van Drenthe en Overijssel (Figuur 3.3) denkbaar. Een oorzaak zou kunnen zijn dat de GVG in Drenthe en Overijssel is bepaald voor plekken met keileem en daardoor onnauwkeurig is in verband met het optreden van schijnspiegels. Volgens de bodemkaart van Nederland, schaal 1 : 50.000, ligt slechts één opnamelocatie op keileem. Lokale profielbeschrijvingen zijn echter nodig om de aanwezigheid van keileem als oorzaak van de gevonden verschillen uit te sluiten.

Een andere oorzaak zou kunnen zijn dat de tijdreeksen niet de grondwaterstandsdynamiek van de locaties van de vegetatieopnamen weergeven. Figuur 3.5 laat zien dat de opnamen en meetbuizen in Drenthe gemiddeld dichter bij elkaar te liggen dan de opnamen en meetbuizen van Staatsbosbeheer. Bij de meeste is de afstand minder dan $100 \mathrm{~m}$, maar bij een aantal is het meer dan $1 \mathrm{~km}$. Deze afstanden behoeven geen bezwaar te zijn wanneer in het veld is vastgesteld dat een peilbuislocatie de hydrologische situatie van een locatie van vegetatieopname vertegenwoordigt. 


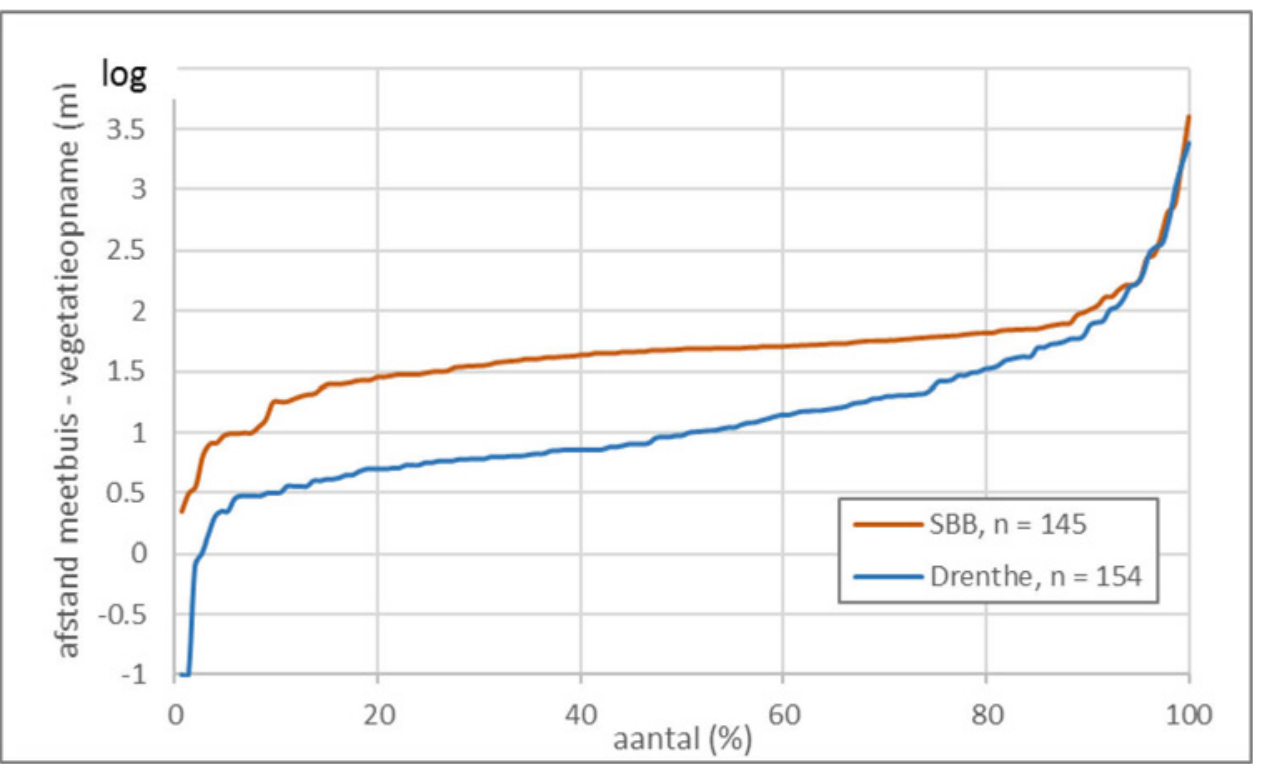

Figuur 3.5 Cumulatieve frequenties van de afstanden van de vegetatieopnamen en het dichtstbijzijnde grondwatermeetpunt. De afstanden in m zijn logaritmisch (log10) getransformeerd.

- In de dataset van Staatsbosbeheer komen alleen ondiepe GVG's ( $<1 \mathrm{~m}$ ) voor, terwijl in de dataset van Drenthe/Overijssel diepere Gt's voorkomen. Aan de hand van de landelijke grondwatertrappenkaart (Bodem- en Gt-kaart, schaal 1 : 50.000) is gekeken welke Gt's bij de peilbuizen voorkomen (Figuur 3.6). Van een aantal plekken is geen Gt bekend, bijvoorbeeld als er petgaten voorkomen.

Hoewel deze vergelijking met een landelijke kaart slechts een globaal beeld geeft, komen er duidelijke verschillen naar voren tussen de dataset van Staatsbosbeheer en die van Drenthe. Bij de meeste meetbuizen van Staatsbosbeheer komt een Gt II voor, terwijl op de peilbuislocaties in Drenthe veel meer drogere Gt's voorkomen. In beide gevallen domineren moerige en venige gronden, maar bij Staatbosbeheer komen ook kleigronden en natte zandgronden (vaag- en beekeerdgronden) voor, terwijl in Drenthe meer plekken met drogere zandgronden (podzolgronden) voorkomen. Detailkarteringen of recentere gegevens kunnen tot andere uitkomsten leiden, maar grosso modo zijn de verschillen tussen beide datasets evident zoals blijkt uit de verschillen in residuele standaardafwijkingen, $s_{\text {res }}$, en verschillen in hellingparameter (vgl. Figuur 3.1 en Figuur 3.3).

- Bij een diepe GVG is de vegetatie grondwateronafhankelijk, maar kan de vegetatie in vochthoudende of kalkrijke gronden toch een hoge GVG indiceren. Hier is verder geen onderzoek naar gedaan.

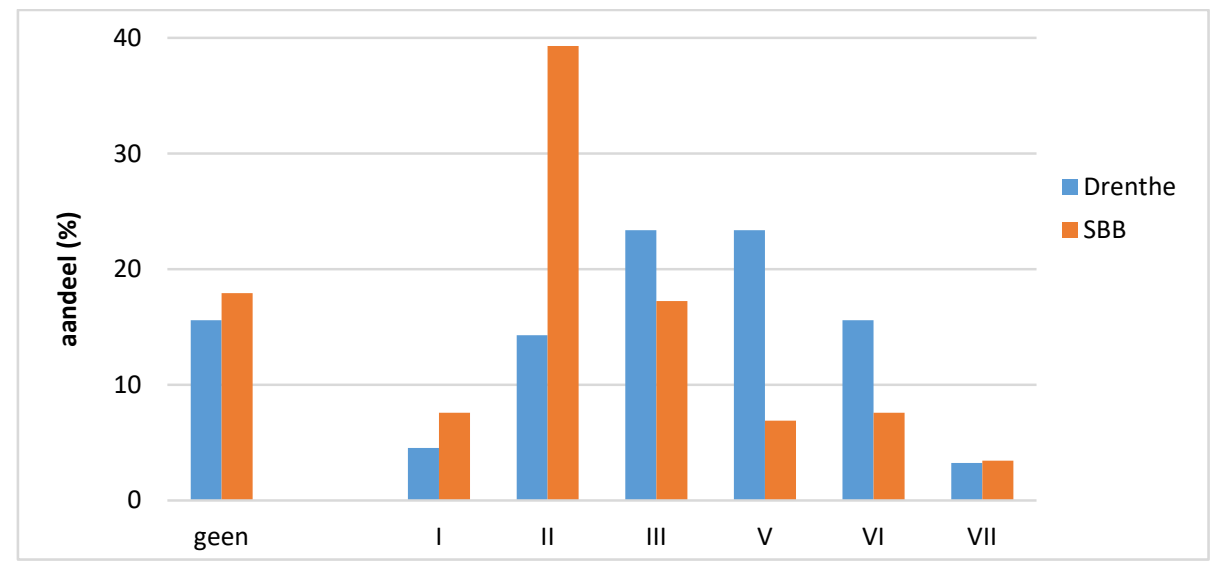

Figuur 3.6 Relatieve frequentieverdeling van de grondwatertrappen bij de meetbuizen van de datasets in Drenthe en van Staatsbosbeheer. 


\section{$4 \quad$ Conclusies en aanbevelingen}

\subsection{Conclusies}

De eerste onderzoeksvraag luidde:

1. Wat zijn de verschillen in de GVG, afgeleid uit vegetatieopnamen met behulp van de verschillende instrumenten of methoden die bij de organisaties KWR, Staatsbosbeheer en WENR (Alterra) zijn ontwikkeld?

De verschillende instrumenten om GVG's uit vegetatieopnamen af te leiden, geven geen eenduidige uitkomsten, maar vertonen grote verschillen. De voorspellingen op basis van Ellenberg (SynBioSys) vertonen een relatief grote spreiding en zijn gemiddeld relatief ondiep. De GVG's die met AI, Estar en Iteratio worden voorspeld vertonen relatief weinig spreiding. Estar voorspelt gemiddeld relatief diepe GVG's.

De tweede onderzoeksvraag was:

2. Wat is de nauwkeurigheid van deze GVG's in vergelijking met die geschat zijn uit tijdreeksen die in peilbuizen zijn waargenomen?

De tweede conclusie is dat de GVG's die uit vegetaties zijn voorspeld niet vergelijkbaar zijn met de GVG's die uit tijdreeksen van grondwaterstanden zijn geschat. De regressiemodellen die de relatie tussen de GVG uit tijdreeksen en de GVG uit vegetatieopnamen beschrijven, hebben residuele standaardafwijkingen variërend van $17 \mathrm{~cm}$ (dataset Staatsbosbeheer, methode Ellenberg) tot $104 \mathrm{~cm}$ (dataset Drenthe-Overijssel, methode Abiotische Indicatoren). Voor het nauwkeurig en gedetailleerd in kaart brengen van de GVG ten behoeve van verdroging is het aantrekkelijk zowel grondwaterstanden in peilbuizen als grondwaterstanden afgeleid uit vegetatieopnamen te combineren om zodoende het meetnet te verdichten. Samenvoegen van GVG's uit beide bronnen vereist echter dat beide vergelijkbare resultaten opleveren, maar uit deze analyse blijkt dat niet het geval te zijn. Er zijn diverse oorzaken denkbaar waardoor de nauwkeurigheid waarmee GVG's uit vegetaties worden voorspeld laag is:

a. Mogelijk zijn de instrumenten waarmee de GVG's uit de vegetatieopnamen zijn afgeleid wel geschikt voor specifieke standplaatsen, maar minder geschikt voor extrapolatie naar regionale of landelijke toepassingen.

b. Vegetaties worden niet zozeer bepaald door langjarige hydrologische condities, zeg gemiddelde condities over een periode van dertig jaar, maar meer door schommelingen met een kortere tijdspanne. Omdat de GVG langjarige condities (dertig jaar) karakteriseert, zijn vegetaties met hogere dynamiek daarom minder geschikte voorspellers voor de GVG.

c. Vegetaties kunnen na-ijlen ten opzichte van wijzigingen in het hydrologische regime, waardoor ze een eerdere hydrologische situatie vertegenwoordigen in plaats van de actuele.

d. Veranderingen in de vochttoestand kunnen op verschillende standplaatsen anders uitpakken als gevolg van verschillen in bodemopbouw en samenstelling van het grondwater.

e. Er is geen relatie tussen de grondwaterstand en de hoeveelheid en samenstelling van het vocht dat beschikbaar is voor de vegetatie. Dit zal vooral bij hangwaterprofielen het geval zijn.

Samenvattend is er geen generale oorzaak aan te wijzen waardoor de uitkomsten uiteenlopen. Op iedere plek kan dat anders zijn. 


\subsection{Aanbevelingen}

Dit onderzoek leidt tot de volgende aanbevelingen:

1. Cruciaal voor een goede analyse van de nauwkeurigheid waarmee uit vegetaties GVG's kunnen worden voorspeld, is dat de locaties van peilbuizen en vegetatieopnamen samenvallen of in elk geval overeenkomstige abiotische condities vertegenwoordigen. Wij bevelen aan om op basis van veldkennis en nauwkeurige informatie over ruimtelijke coördinaten de datasets te screenen. Herhaling van de analyses met een gescreende dataset kan wellicht resulteren in hogere voorspelnauwkeurigheden.

2. Wij bevelen aan om de instrumenten om GVG's uit vegetatie te voorspellen, te verbeteren, door meer gewicht te geven aan de minder dynamische eigenschappen van een vegetatie. De GVG is immers een karakteristiek voor langjarige hydrologische condities (dertig jaar).

3. Omdat de relatie tussen vegetatie en GVG afhangt van bodemkundige en hydrologische omstandigheden, bevelen wij aan om in de instrumenten die de GVG uit vegetatie voorspellen meer differentiatie aan te brengen naar deze omstandigheden. 


\section{Literatuur}

Asmuth, J.R. von, M.F.P. Bierkens en C. Maas, 2002. Transfer function noise modeling in continuous time using predefined impulse response functions. In: Water Resources Research, jrg 38, nr 12, pag. 23-1 - 23-12

Asmuth, J.R. von, 2012. Groundwater System Identification through Time Series Analysis. Ph.D. thesis, Technical University Delft.

Beets, C., P.W.F.M. Hommel en R.W. de Waal, 2000. Selectie van referentiepunten t.b.v. het SBBproject terreincondities. Fase 1: resultaten inventarisatie 1999. Staatsbosbeheer/Alterra. http://edepot.wur.nl/186155

Beets, C., P.W.F.M. Hommel en R.W. de Waal, 2001. Selectie van referentiepunten t.b.v. het SBBproject terreincondities. Fase 2: resultaten inventarisatie 2000. Staatsbosbeheer/Alterra. http://edepot.wur.nl/186156

Beets, C., P.W.F.M. Hommel en R.W. de Waal, 2002. Selectie van referentiepunten t.b.v. het SBBproject terreincondities. Fase 3: resultaten inventarisatie 2001. Staatsbosbeheer/Alterra. http://edepot.wur.nl/186157

Beets, C., P.W.F.M. Hommel en R.W. de Waal, 2003. Selectie van referentiepunten t.b.v. het SBBproject terreincondities. Fase 4: resultaten inventarisatie 2002. Staatsbosbeheer/Alterra. http://edepot.wur.nl/186152

Beets, C., P.W.F.M. Hommel en R.W. de Waal, 2004. Selectie van referentiepunten t.b.v. het SBBproject terreincondities. Fase 5: resultaten inventarisatie 2003. Staatsbosbeheer/Alterra. http://edepot.wur.nl/186154

Beets, C., P.W.F.M. Hommel en R.W. de Waal, 2005. Selectie van referentiepunten t.b.v. het SBBproject terreincondities. Resultaten inventarisatie 2004. Staatsbosbeheer/Alterra. http://edepot.wur.nl/186153

Delft, S.P.J. van, T. Hoogland, W.M.L. Meijninger en G.J. Roerink, 2017. Verdrogingsinformatie voor de Nederlandse natuur; Een vergelijking tussen de actuele en gewenste grondwatersituatie. Wageningen, Wageningen Environmental Research, rapport 2792.

Hennekens, S.M., N.A.C. Smits en J.H.J. Schaminée, 2010. SynBioSys Nederland versie 2. Alterra, Wageningen UR.

Holtland, W.J., C.J.F. ter Braak en M.G.C. Schouten, 2010. Iteratio: calculating environmental indicator values for species and relevés. Applied Vegetation Science 13: 369-377.

Hommel, P.W.F.M., E. Brouwer, E.C.H.E.T. Lucassen, A.J.P. Smolders en R.W. de Waal, 2006. Een verkennend onderzoek aan de hand van 92 SBB-referentiepunten: selectie van ecologisch relevante bodemeigenschappen. Wageningen, Alterra-rapport 1445.

Knotters, M. en T. Hoogland, 2015. Validatiemeetnet voor grondwaterstandinformatie over verdroging. Fase 1: probleemverkenning en inventarisatie. Wageningen, Alterra-rapport 2660.

Lock, M., M. Scherphuis en P. van der Molen, 2015. Inventarisatie Rekentools Abiotiek. Utrecht, BIJ12. 
Shibata, R., 1976. Selection of the order of an autoregressive model by Akaike's information criterion. Biometrika 63: 117-126.

Vullings, W. en D. Walvoort, 2016. Kwaliteit en ruimtelijke Big Data. Onderzoeksagenda. ESG, Wageningen UR, Expertisecentrum Kwaliteit van Ruimtelijke Data (EKRD), WOt-notitie.

Waal, R.W. de en P.W.F.M. Hommel, 2013. Provinciaal meetnet verdroging Overijssel: beschrijving en beoordeling van 56 meetpunten. Wageningen, Alterra-rapport 2457. 


\section{Bijlage 1}

Scatterplots van de GVG van het freatische grondwater en de GVG's volgens verschillende indicatiemethoden van de vegetatieopnamen, gebaseerd op de dataset van Staatsbosbeheer. Alleen GVG's die geschat zijn met een tijdreeksmodel waarvan het percentage verklaarde variantie groter is dan $70 \%$ zijn beschouwd. $S_{r e s}$ : residuele standaardafwijking. $\mathrm{R}^{2}$ adj. : fractie verklaarde variantie. $\mathrm{n}$ : aantal waarnemingen.

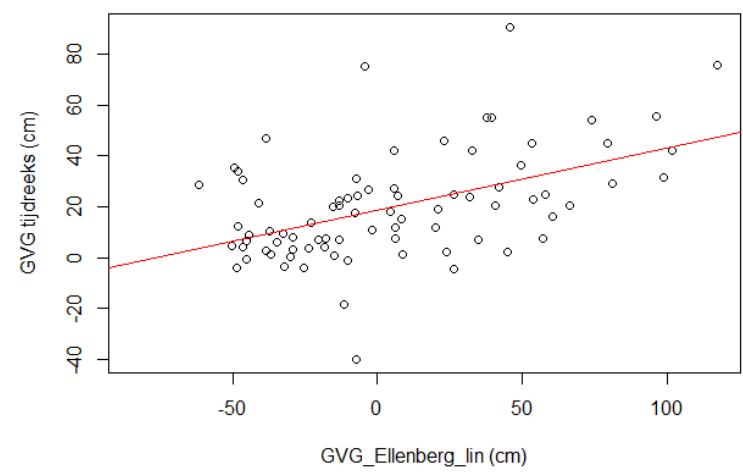

$$
\begin{aligned}
& \mathrm{y}=18.53+0.25 \mathrm{x} \\
& (2.08) \quad(0.05) \\
& \mathrm{S}_{\text {res }}=18.63 \mathrm{~cm} \\
& \mathrm{R}^{2}{ }_{\text {adj }}=0.23 \\
& \mathrm{n}=81
\end{aligned}
$$

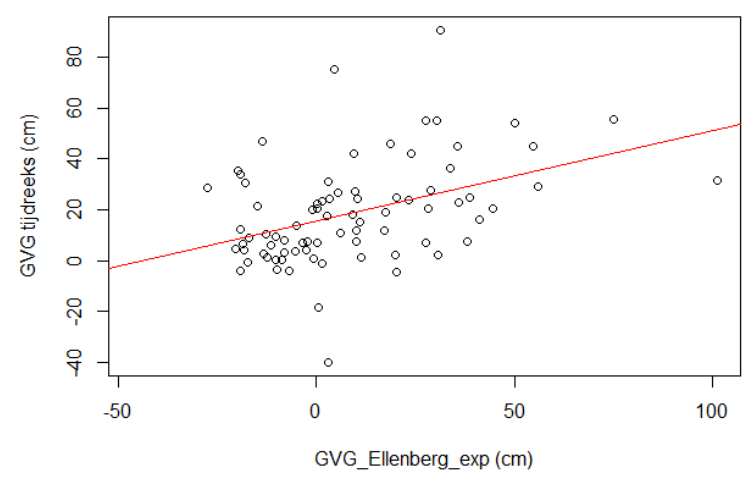

$$
\begin{aligned}
& \mathrm{y}=15.50+0.36 \mathrm{x} \\
& (2.24) \quad(0.09) \\
& \mathrm{S}_{\text {res }}=18.65 \mathrm{~cm} \\
& \mathrm{R}^{2}{ }_{\text {adj }}=0.16 \\
& \mathrm{n}=79
\end{aligned}
$$

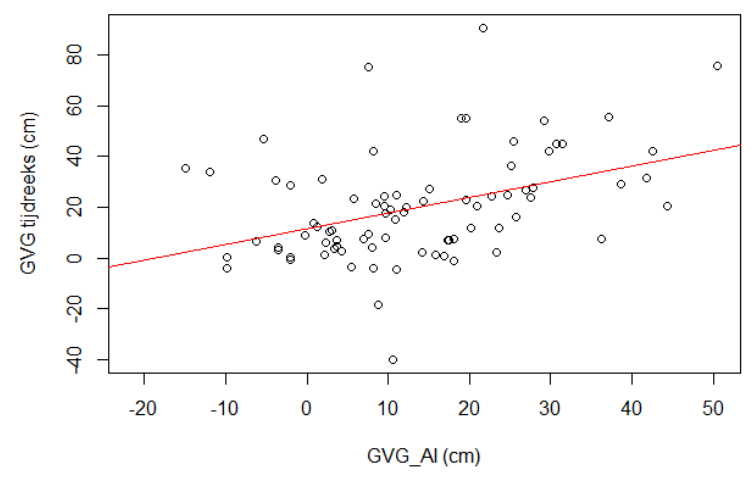

$$
\begin{aligned}
& \mathrm{y}=11.52+0.61 \mathrm{x} \\
& \quad(3.02) \quad(0.16) \\
& \mathrm{S}_{\text {res }}=19.58 \mathrm{~cm} \\
& \mathrm{R}_{\text {adj }}=0.15 \\
& \mathrm{n}=81
\end{aligned}
$$




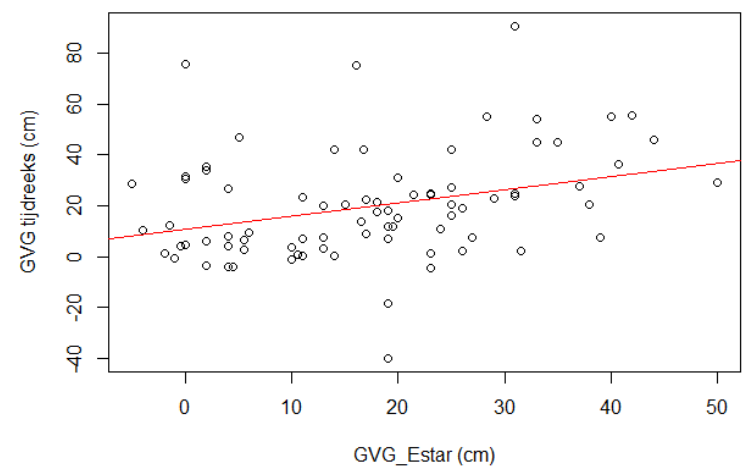

$$
\begin{aligned}
& \mathrm{y}=10.80+0.51 \mathrm{x} \\
& \quad(3.78) \quad(0.17) \\
& \mathrm{S}_{\text {res }}=20.31 \mathrm{~cm} \\
& \mathrm{R}^{2}{ }_{\text {adj }}=0.09 \\
& \mathrm{n}=81
\end{aligned}
$$
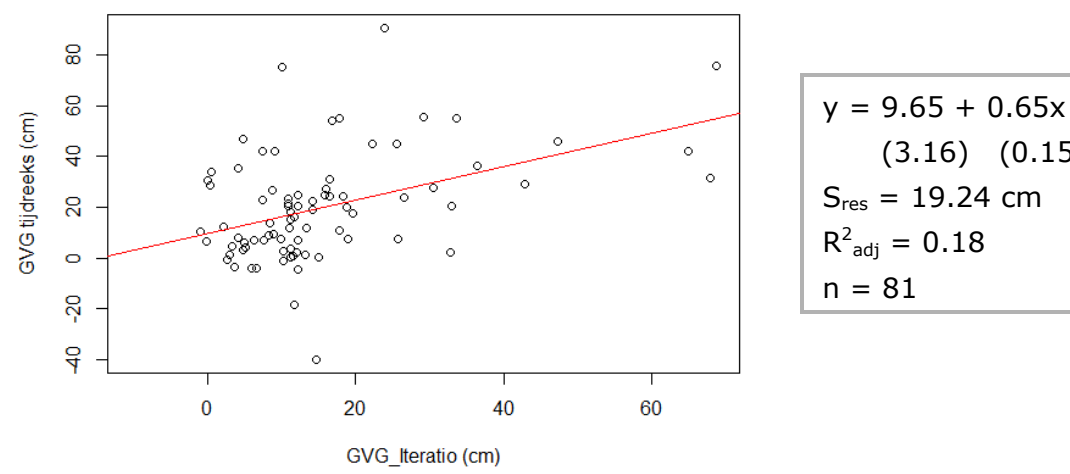

Boxplots van de GVG's, berekend uit tijdreeksen (GVG) en GVG's die met verschillende modellen uit vegetatieopnamen zijn geschat. Value: berekende GVG in cm-mv.

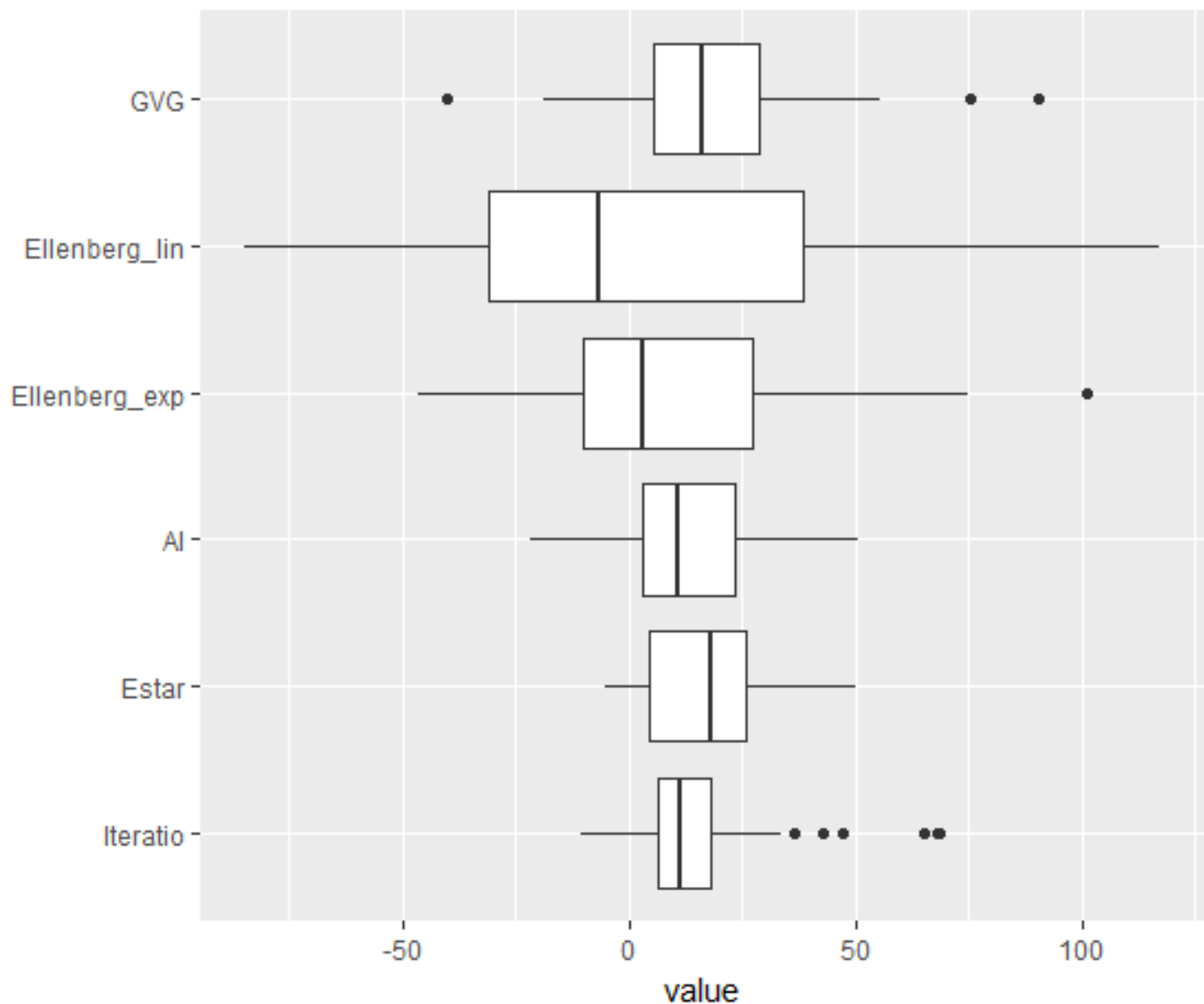




\section{Bijlage 2}

Scatterplots van de GVG van het freatische grondwater en de GVG's volgens verschillende indicatiemethoden van de vegetatieopnamen, gebaseerd op de dataset van Staatsbosbeheer. Alleen GVG's die geschat zijn met een tijdreeksmodel waarvan de visuele beoordeling van de fit van de modellen goed of zeer goed is, zijn beschouwd. Sres: residuele standaardafwijking. $\mathrm{R}^{2}$ adj.: fractie verklaarde variantie. $\mathrm{n}$ : aantal waarnemingen.

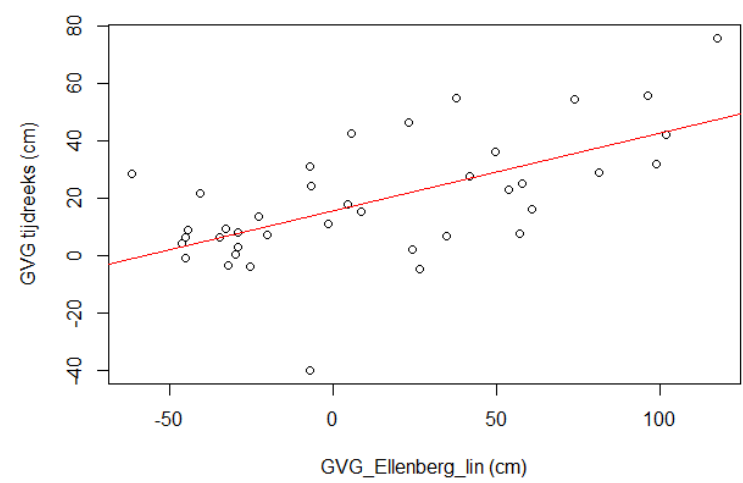

$$
\begin{aligned}
& \mathrm{y}=15.56+0.27 \mathrm{x} \\
& (2.84) \quad(0.06) \\
& \mathrm{S}_{\text {res }}=17.16 \mathrm{~cm} \\
& \mathrm{R}^{2}{ }_{\text {adj }}=0.36 \\
& \mathrm{n}=39
\end{aligned}
$$

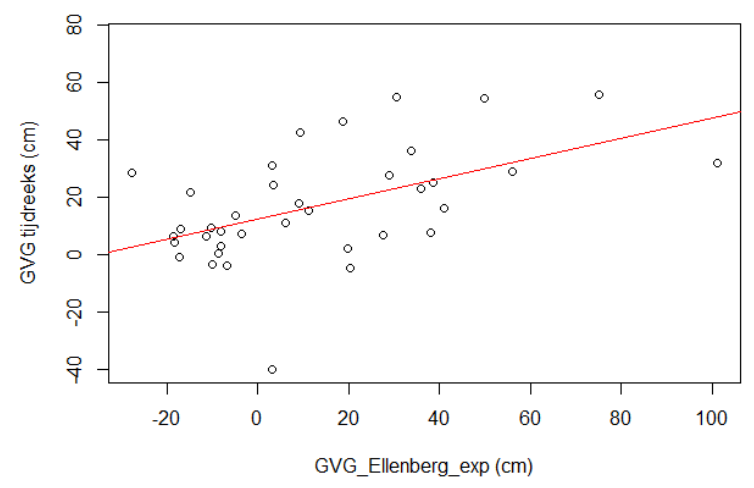

$$
\begin{aligned}
& \mathrm{y}=12.30+0.35 \mathrm{x} \\
& (3.06)(0.10) \\
& \mathrm{S}_{\text {res }}=16.94 \mathrm{~cm} \\
& \mathrm{R}^{2}{ }_{\text {adj }}=0.24 \\
& \mathrm{n}=37
\end{aligned}
$$

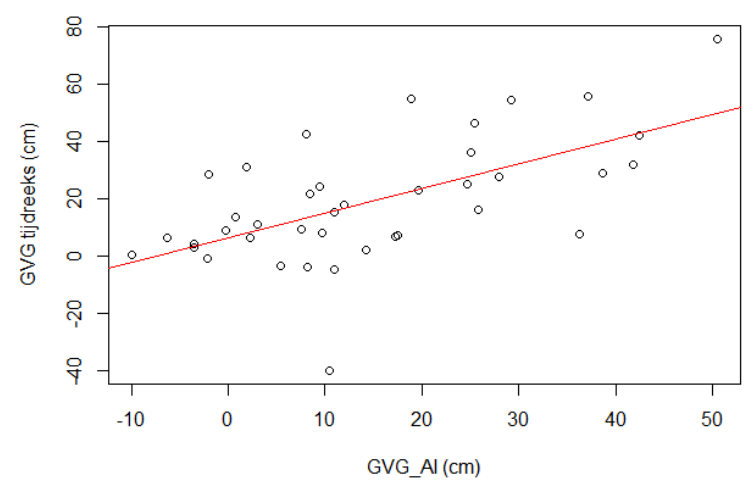

$$
\begin{aligned}
& \mathrm{y}=6.33+0.86 \mathrm{x} \\
& \quad(3.06) \quad(0.10) \\
& \mathrm{S}_{\text {res }}=17.36 \mathrm{~cm} \\
& \mathrm{R}^{2}{ }_{\text {adj }}=0.35 \\
& \mathrm{n}=39
\end{aligned}
$$




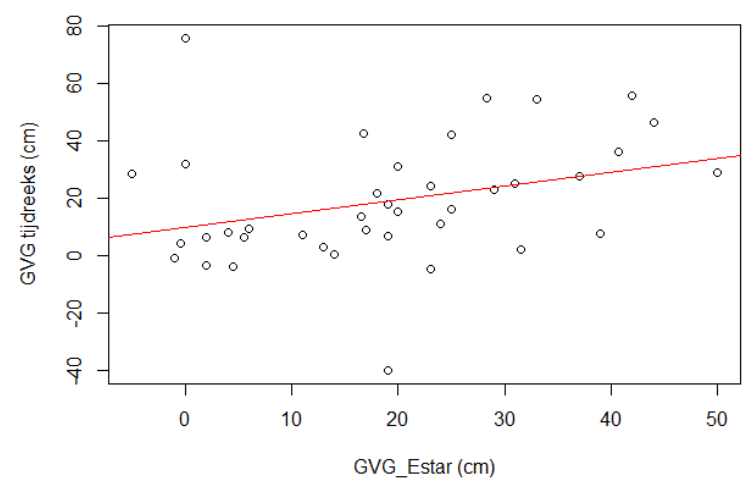

$$
\begin{aligned}
& \mathrm{y}=9.84+0.48 \mathrm{x} \\
& \quad(5.59) \quad(0.24) \\
& \mathrm{S}_{\text {res }}=20.68 \mathrm{~cm} \\
& \mathrm{R}^{2}{ }_{\text {adj }}=0.08 \\
& \mathrm{n}=39
\end{aligned}
$$

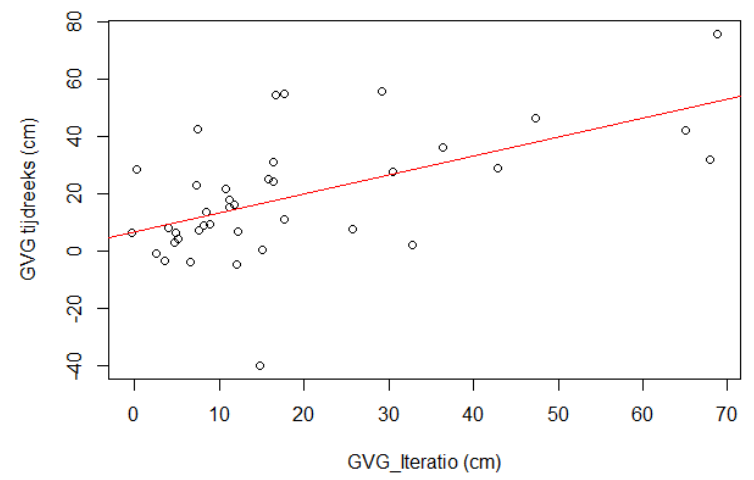

$$
\begin{aligned}
& \mathrm{y}=6.60+0.66 \mathrm{x} \\
& \quad(4.17) \quad(0.16) \\
& \mathrm{S}_{\text {res }}=18.05 \mathrm{~cm} \\
& \mathrm{R}_{\text {adj }}^{2}=0.30 \\
& \mathrm{n}=39
\end{aligned}
$$

Boxplots van de GVG's, berekend uit tijdreeksen (GVG) en GVG's die met verschillende modellen uit vegetatieopnamen zijn geschat. Value: berekende GVG in cm-mv.

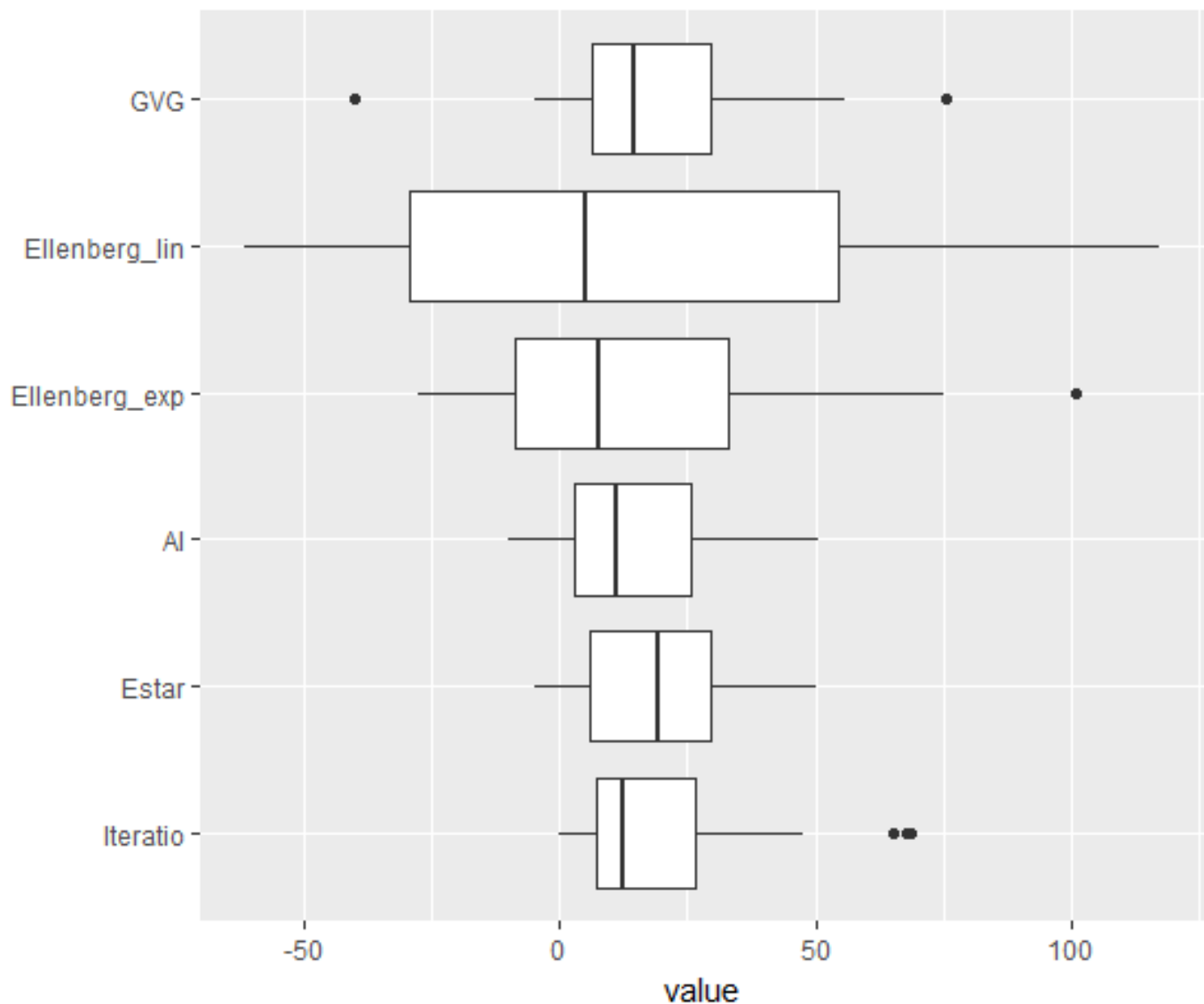




\section{Bijlage 3}

Scatterplots van de GVG van het freatische grondwater en de GVG's volgens verschillende indicatiemethoden van de vegetatieopnamen, gebaseerd op de dataset van Staatsbosbeheer. Alleen GVG's die geschat zijn met een tijdreeksmodel dat is gefit op een meetreeks van minimaal vijf jaar zijn beschouwd. Sres: residuele standaardafwijking. $\mathrm{R}^{2}$ adj. : fractie verklaarde variantie. $\mathrm{n}$ : aantal waarnemingen.

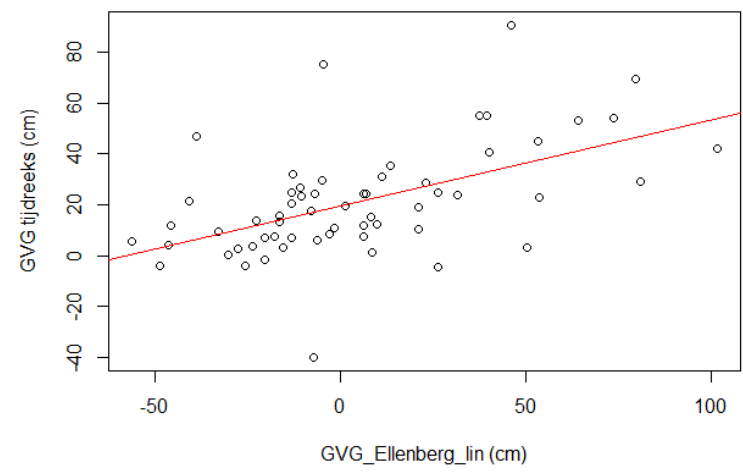

$$
\begin{aligned}
& \mathrm{y}=19.49+0.34 \mathrm{x} \\
& (2.41) \quad(0.07) \\
& \mathrm{S}_{\text {res }}=18.47 \mathrm{~cm} \\
& \mathrm{R}^{2}{ }_{\text {adj }}=0.28 \\
& \mathrm{n}=60
\end{aligned}
$$

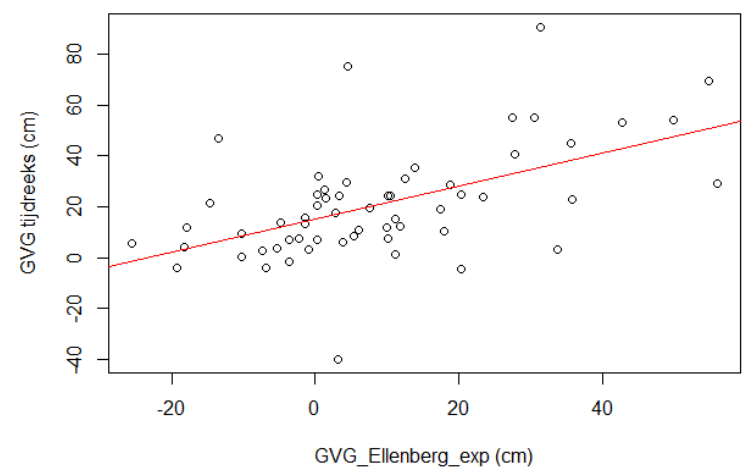

$$
\begin{aligned}
& \mathrm{y}=15.03+0.65 \mathrm{x} \\
& (2.68) \quad(0.13) \\
& \mathrm{S}_{\text {res }}=18.48 \mathrm{~cm} \\
& \mathrm{R}^{2}{ }_{\text {adj }}=0.28
\end{aligned}
$$$$
\mathrm{n}=59
$$

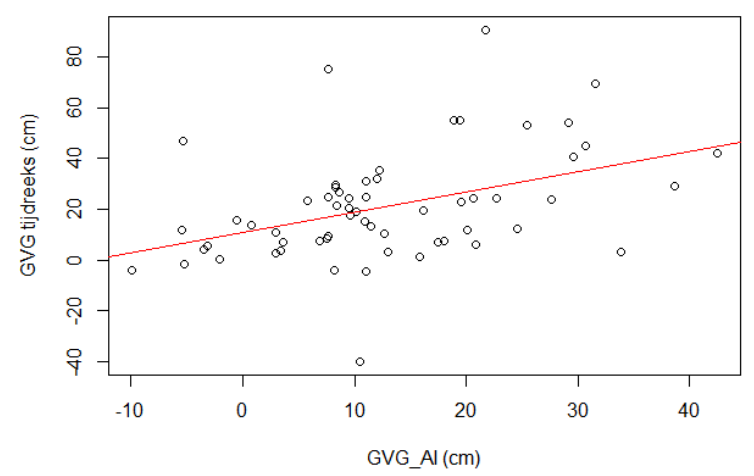

$y=10.97+0.80 x$

$\mathrm{S}_{\text {res }}=19.98 \mathrm{~cm}$

$\mathrm{R}^{2}{ }_{\mathrm{adj}}=0.16$

$\mathrm{n}=60$ 


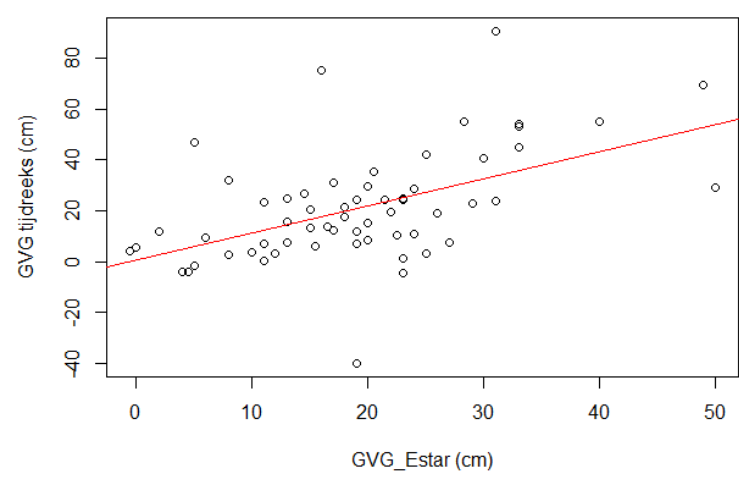

$$
\begin{aligned}
& \mathrm{y}=0.66+1.07 \mathrm{x} \\
& \quad(5.06) \quad(0.23) \\
& \mathrm{S}_{\text {res }}=18.79 \mathrm{~cm} \\
& \mathrm{R}^{2}{ }_{\text {adj }}=0.26 \\
& \mathrm{n}=60
\end{aligned}
$$

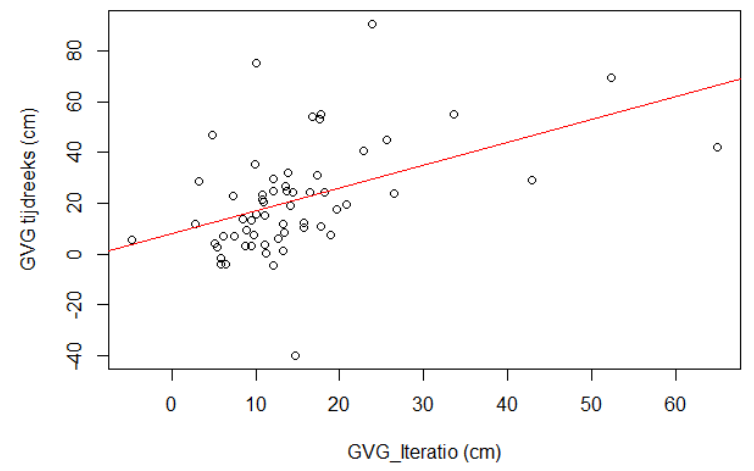

$y=7.84+0.90 x$

(4.19) (0.23)

$\mathrm{S}_{\text {res }}=19.49 \mathrm{~cm}$

$\mathrm{R}^{2}$ adj $=0.20$

$\mathrm{n}=60$

Boxplots van de GVG's, berekend uit tijdreeksen (GVG) en GVG's die met verschillende modellen uit vegetatieopnamen zijn geschat. Value: berekende GVG in cm-mv.

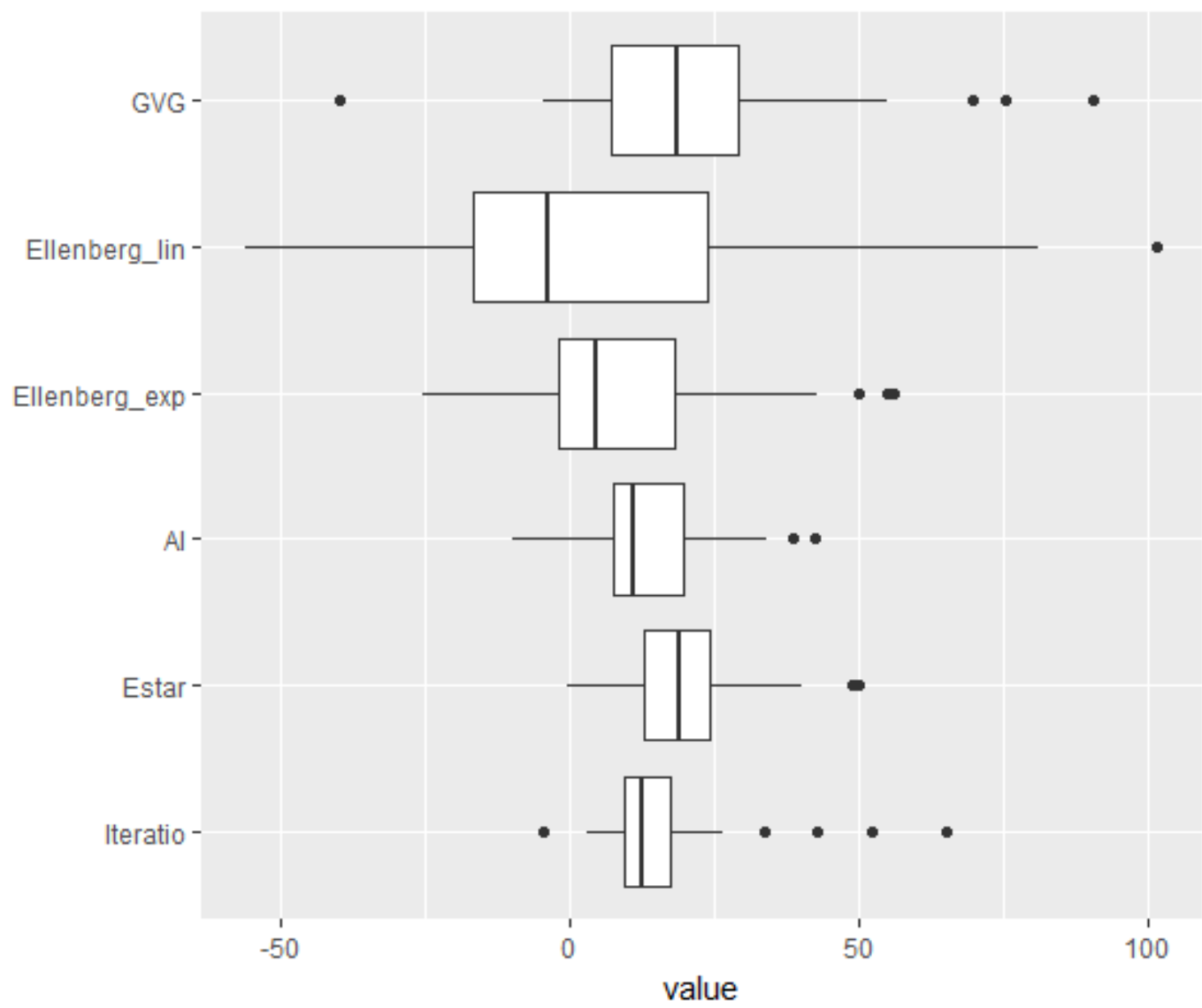


Wageningen Environmental Research Postbus 47

6700 AA Wageningen

T 0317480700

www.wur.nl/environmental-research

Wageningen Environmental Research Rapport 2869

ISSN 1566-7197
De missie van Wageningen University \& Research is 'To explore the potential of nature to improve the quality of life'. Binnen Wageningen University \& Research bundelen Wageningen University en gespecialiseerde onderzoeksinstituten van Stichting Wageningen Research hun krachten om bij te dragen aan de oplossing van belangrijke vragen in het domein van gezonde voeding en leefomgeving. Met ongeveer 30 vestigingen, 5.000 medewerkers en 10.000 studenten behoort Wageningen University \& Research wereldwijd tot de aansprekende kennisinstellingen binnen haar domein. De integrale benadering van de vraagstukken en de samenwerking tussen verschillende disciplines vormen het hart van de unieke Wageningen aanpak. 



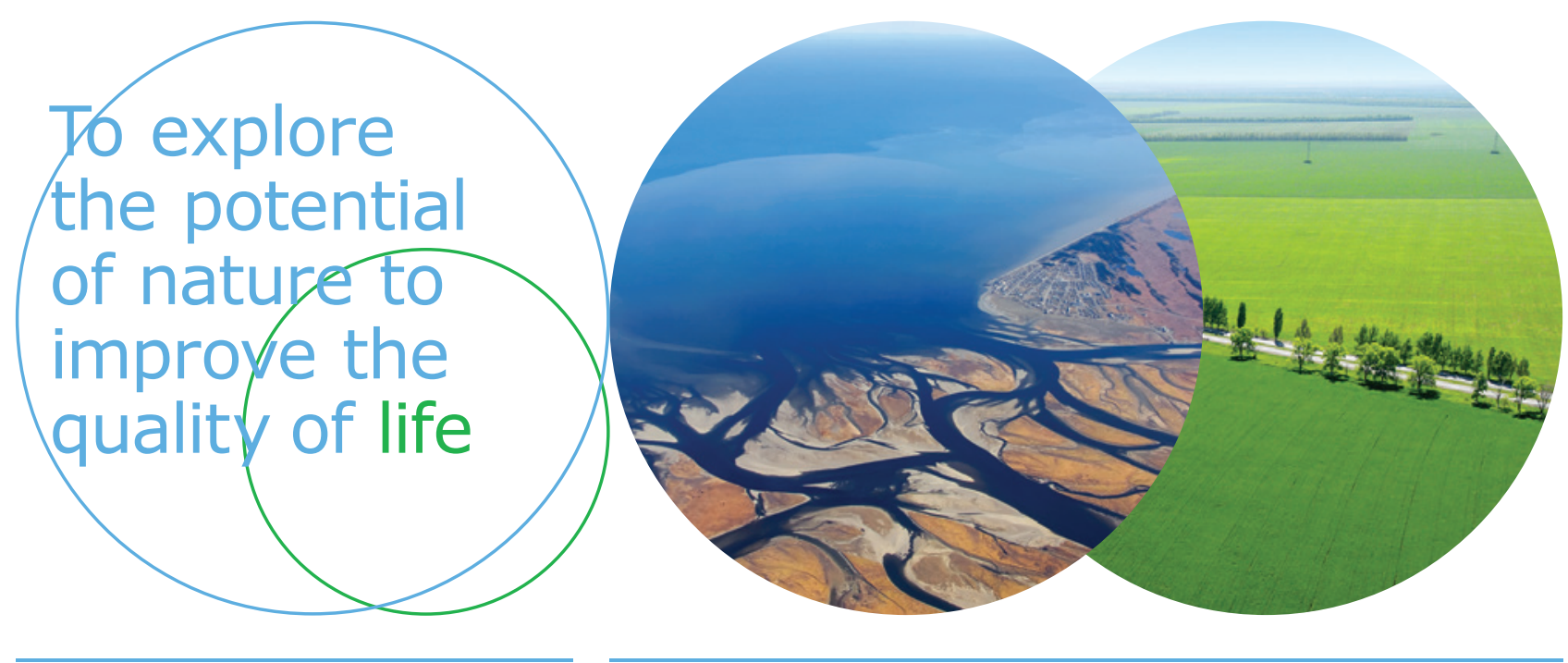

Wageningen Environmental Research Postbus 47

$6700 \mathrm{AB}$ Wageningen

T 317480700

www.wur.nl/environmental-research

Rapport 2869

ISSN 1566-7197
De missie van Wageningen University \& Research is 'To explore the potential of nature to improve the quality of life'. Binnen Wageningen University \& Research bundelen Wageningen University en gespecialiseerde onderzoeksinstituten van Stichting Wageningen Research hun krachten om bij te dragen aan de oplossing van belangrijke vragen in het domein van gezonde voeding en leefomgeving. Met ongeveer 30 vestigingen, 5.000 medewerkers en 10.000 studenten behoort Wageningen University \& Research wereldwijd tot de aansprekende kennisinstellingen binnen haar domein. De integrale benadering van de vraagstukken en de samenwerking tussen verschillende disciplines vormen het hart van de unieke Wageningen aanpak. 